\title{
On Justified Rule Departures by Officials ${ }^{\dagger}$
}

\author{
Mortimer R. Kadish* \\ Sanford H. Kadish**
}

Legal systems such as our own govern those over whom their authority extends partly through mandatory rules. Mandatory rules are those officially authenticated rules or commands that aim to impose a legal obligation to comply upon persons they address. They are distinguishable from rules that purport only to signify the legal consequences of designated conduct, and leave their addressees free of any legal obligation to choose one course of conduct and consequence over another.

Mandatory rules are of two sorts. There is first the kind that most naturally comes to mind: those which direct compliance with specified standards of behavior on pain of punishment. Rules of this type exhibit their mandatory character both in their form ("No one shall ...." "You shall not . . .," "It is a crime to . . .") and in the explicit threat of formal punishment for noncompliance. We shall call them "peremptory rules" and include in the category orders given by authorized officials to individuals. Such are the rules of criminal law, the orders of administrative or judicial tribunals, and the orders of individual officials, such as policemen. We distinguish these rules only for the purpose of setting them aside for the purposes of this Article.

The second kind of mandatory rule is the kind with which we have chosen to deal here. They are addressed to governmental officials as such and derive their mandatory import not from the threat of formal punishment (which may or may not exist), but from the inherently restricted role of those officials as recipients of a $\mathrm{bm}$ ited governmental authority. We shall call these rules "rules of competence." For exainple: The jury is to decide in accordance with the law given by the judge; the administrative agency is to give dispositive

$\dagger$ This Article is adapted from part of a book the authors are in progress of writing on the justification of rule departures.

* Professor of Philosophy, Case Western Reserve University. B.S.S. 1938, City College of New York; M.A. 1939, Ph.D. 1950, Columbia University.

** Professor of Law, University of California, Berkeley. B.S.S. 1942, City College of New York; LL.B. 1948, Columbia University. 
weight to one single factor in reaching a decision, or is to disregard that factor entirely, or is to consider that factor only in conjunction with other factors; the magistrate is to set bail on the basis of its need to insure the defendant's presence at the trial; the judge is not to grant probation in defined classes of cases. These rules are plainly not options offered the official. They are the terms under which he is given governmental power. When he does not comply his action is unauthorized, and officials are no less obliged to refrain from committing unauthorized acts than are citizens in general obliged to refrain from punishable ones.

But suppose the jury decides otherwise than in accordance with the law given by the judge. Suppose the administrative agency does not give dispositive weight to the factor to which it is required to give such weight. Suppose the magistrate does not set bail solely on the basis of the need to assure the defendant's presence at the trial, or that the judge, considering the particular situation, does grant probation to persons disentitled to receive it. Granting the mandatory character of the rules of competence involved, does the legal systein necessarily condemn all such actions in violation of those rules and deprive those actions of all legitimacy? For many, or perhaps even most cases, no doubt it does. Yet we propose that our legal system does not always, or necessarily, do so and that its very organization may, at various critical points, furnish the justification for officials taking upon themselves actions that depart from some rule circumscribing their competence. We suggest that the obligations that rules of competence impose are not unremitting in all legally defined official roles. In virtue of the nature of the office and its place in the legal system, an official may sometimes be justified, as the official he is, in taking upon himself the decision to depart from some rule of competence and hence from some incurred obligation. That is the proposition this Article seeks to support. But first, a few preliminary observations on our usage of the term "rule departure."

We have employed the neutral term "departure" rather than "violation" or some equivalent because if there are offices in the legal systein that indeed permit departures from rules of competence in our sense, it would be inappropriate to characterize the departure as a violation. For violation implies, flat-out, that that has been done that ought not to have been done; but if there are rule departures of the sort here at issue, then while that which was done is of the sort that is not supposed to be done, the undertaking of the action was justified.

Violations aside, then, with respect to some specific rule of competence, a rule departure might occur in the sense of breaking or bending, or of ignorimg or failing to give adequate consideration to the 
rule. A demand has, in fact, been refused. We speak of "bending" or "breaking," or "ignoring" or "failing to give adequate consideration to" in order to acknowledge that not all rules of competence lie on the same logical level. Between the rule of stare decisis, for example, and the rules that bind a clerk's behavior at a marriage license bureau or even the instructions that a court may give to a jury on the law, there are at least prima facie significant differences. The jury might be said to defy the instructions of the court and thereby to break the law, if that is the law; the clerk might, deliberately or not, omit some act that he is required to perform; but it is prima facie liard to see low a court could "break" the rule of stare decisis. They might "ignore" stare decisis (if, indeed, conformity to that rule is conformity to a rule of judicial competence) or give it inadequate consideration; yet the rule is inuch too fluid to "break." Sone might prefer to call such a rule a "policy." But, even so, if stare decisis, or any other policy, standard, norm, or rule is to have a determinate character and function in decision, it must be possible at some point to say that the official over whom it rules as a rule of competence has departed froin it-and this whatever the mode of departure.

We turn now to the central issue of this Article: When and in what circumstances does our legal system afford ground for concluding that an official is justified in undertaking to depart from a rule of coinpetence that constrains him in his official role?

\section{I}

\section{The Rule of LAW MOdel aNd the Role of the OfFicial}

The received formulation of the role and obligation of officials in our legal systein with respect to rules of competence is epitomized in the conception of the rule of law. The phrase lias been impressed for service in a variety of causes and has attracted to itself over the years a variety of meanings associated with various attributes of the good legal order. It is sometimes used to embrace the rights of man in the large sense. It is also used to refer to the procedural guarantees available to individuals against governmental action of the kind specified in the Bill of Rights. At other times the reference is to the substitution of legal procedures for force in the resolution of international or domestic disputes. The meaning of most direct relevance for our purposes, however, is conveyed by the terms "supremacy of law" and "a government of laws and not of men." So taken, the rule of law constitutes an ideal model of legal authority in which governance by rules is paramount over government by the will of those lolding official power. Its roots go back to medieval times when the theory prevailed that "law of 
some kind-the law either of God or man-rules the world." It became entrenched in Englisli constitutional law following the Stuart period when the judges and Parliament invoked the supremacy of the law against the royal prerogative.

As Dicey formulated the rule of law, it has two fundamental meanings. First, it means "the absolute supremacy or predominance of regular law as opposed to the influence of arbitary power, and excludes the existence of arbitrariness, of prerogative, or even of wide discretionary authority on the part of government." Secondly, it means "the equal subjection of all classes to the ordinary law of the land administered by the ordinary law courts" and "excludes the idea of any exemption of officials or others from the duty of obedience to the law which governs other citizens or from the jurisdiction of the ordinary tribunals."

More recent formulations voice similar themes. Professor Hayek tells us that the rule of law means that "government in all its actions is bound by rules fixed and announced beforehand-rules which make it possible to foresee with fair certainty low the authority will use its coercive powers in given circumstances. . . Within the known rules of the game the individual is free to pursue his personal ends and desires, certain that the powers of government will not be used deliberately to frustrate his efforts."

Essentially, then, the rule of law states a rule-conforming model for those who exercise government authority. The expositors of the rules are the law courts, who perform their roles within the rigorous confines of the discipline of cominon law reasoning and principles. The legislature, and only the legislature, may alter those rules: in England, under the doctrine of parhianentary sovereignty, subject to no judicial review; in the United States, subject to written constitutional restraints interpreted by the courts. But apart from the legislating function, the process of governing under the rule of law excludes the official's personal evaluation and choice. As Duguit observed, "No organ of the State may render an individual decision which would not conforin to a general rule previously stated." All the choices are reflected in the rules.

1. 10 W. HoldsWORTH, A History OF ENGLISH LAW 647 (1938).

2. A. Dicey, Introduction to the Study of the LAW of the Constitution 202-03 (10th ed. 1961).

3. F. Hayek, The Road to Serfodom $72-73$ (1944). A modern study of administrative agencies concludes: "The rule of law stands for the view that decisions sliould be made by the application of known principles or laws. In general such decisions will be predictable, aud the citizen will know where le is. On the other hand there is what is arbitrary. A decision may be made without principle, without any rules. It is therefore unpredictable, the antithesis of a decision taken in accordance with the rule of law." Gr. Brit. Commttre on Administrative Tribunars, CMnd. No. 218, at 6 (1957).

4. L. DugutT, Tratté DE Drott Constitutionnel 681 (3d ed. 1927). 
The obligation of the person exercising governmental authority is to act always in complete conformity with them. It is never up to him to do otherwise. The legal official is a wheel in the machine; he nay never be its ghost.

This way of regarding legal officials responds to considerations of fairness and protection against abuse of power. It leaves no room for arbitrary or capricious use of state power. In eliminating the personal in decisionmaking, it enhances the value of equal treatment for all. And in insisting on conformity with stated rules, it provides the necessary condition for the governed to plan their conduct in accordance with reliably predictable outcomes.

The traditional rule of law, then, is a description of the role of the official that protects in two ways against the injection of his personal will into the exercise of governmental power. First, it precludes all action that is not delegated by law and all action taken on the basis of considerations precluded by law. Second, it requires that the action authorized and the grounds for taking the action be sufficiently clear and complete to permit of no major exercise of judgment by the official. Dicey spoke to the first point when he observed that the rule of law "excludes the existence of arbitrariness, of prerogative." He explicitly embraced the second when he observed that it also excludes "wide discretionary authority on the part of the government." Both points serve to restrain discretionary judgment by the official. The first bars what we may term "deviational discretion;" that is, the exercise of authority in ways, or upon the basis of considerations, not authorized, or even prohibited, by law. The second severely limits even legally delegated discretion.

\section{A. Delegated Discretion}

This last-stated corollary of the rule of law is no longer regarded as one of its essential features; at least, not in anything like the sweeping sense Dicey had in mind. The expansion of the role of government to deal with problems of urbanization, industrialization, and technology in the public interest have made it inevitable that substantial discretionary authority be delegated to governmental officials. The courts continue to insist on a legislative statement of standards to control the exercise of discretion, ${ }^{6}$ but in fact the standards which are lield permissible- "public convenience and necessity," "unjust rates," "unfair methods of competition" - are so wide and general as scarcely to function as realistic

5. A. DiceX, supra note 2, at 202.

6. K.C. Davis, Discretionary Justice 44 (1969).

7. E.g., Interstate Commerce Act $\S 207(a), 49$ U.S.C. $\S 307(a)$ (1964).

8. E.g., Federal Power Act $\$ 206,16$ U.S.C. $\$ 824(\mathrm{e})$ (1964).

9. Federal Trade Commission Act § 5(a)(1), 15 U.S.C. $\$ 45(a)(1)$ (1964). 
restraints. Professor Davis' view of discretion would generally find favor today:

No legal system in world history has been without discretionary power.

None can be. Discretion is indispensable for individualized justice, for creative justice, for new programs in which no one yet knows how to formulate rules, and for old programs in which some aspects cannot be reduced to rules. Eliminating discretionary power would paralyze governmental processes and would stifle imdividualized justice. Those who would forbid governmental coercion except on the basis of rules previously announced seem to me to have misunderstood the elements of law and government. ${ }^{10}$

Therefore the problem today is not the existence of discretionary government, but how, again in Professor Davis' words, "to confine, to structure, and to check" its appropriate exercise. ${ }^{11}$

\section{B. Deviational Discretion}

The same, of course, cannot be said of the first mentioned corollary of the rule of law-that government power may not be exercised in ways precluded by the rules creating the discretionary authority. Official actions outside the boundaries of the rules of law explicitly defining the official's authority are characteristically seen as usurpations of legal power incompatible with the minimum content of a law-governed community. Deviational discretion is lawlessness.

Why this continues to seem so, despite the acceptance of wide discretionary judgment of officials within delegated limits, is obvious enough, but it will be helpful to state the obvious at this point. Delegated discretion can be defended on grounds that some discretion is inescapable for a rational and just system of law and that a variety of constraints are available to foster the rational and principled exercise of discretionary authority. Deviational discretion is another inatter. . Not only does it entail deciding the substantive issue without controlling legal guidance, but also a determination that the official may properly decide to disregard the answer provided by law in favor of a judgment on the merits which he alone makes. Put another way, delegated discretion puts the substantive issue up to the official, but deviational discretion involves the official taking it upon himself to determine whether to produce the decision that the law provides or to fashion a different one.

In a word, discretion is one thing; discretion to determine competence to exercise discretion is another. A community need not forfeit its claim to being ordered by law because it vests in officials discre-

10. K.C. DAVSs, supra note 6, at 216-17 (footnotes omitted).

11. Id. at 4 . 
tionary authority over the resolution of substantive issues; but it seems that it does if it accepts the freedom of officials to assume a discretion to redefine their authority and role to embrace a competence denied by law. The obligation of officials of the law to act in accordance with law is what it means to say that a system is governed by law, if one accepts the rule of law model.

\section{II}

\section{An Exploration of Otherwise Patterned Official Roles: The Criminal Jury}

The conventional rule of law model, then, permits of no justification for officials to undertake on their own to depart from the mandatory rules of competence the law lays upon them. We want to argue, however, that the rule of law model, so far as it states an ideal for the functioning of legal systems, is not necessarily the best ideal; that so far as it contemplates a description of the roles and obligations of officials in our legal system, it partially misdescribes; that, consequently, so far as it states a definition of what it means to function as a legal system, it fails. While acknowledging that roles constructed according to the rule of law model do indeed exist within the legal system, and, indeed, in many areas may even be the prevailing roles, the following pages will try to show that our legal system sometimes affords officials roles that allow for the exercise of deviational discretion - that is, of judginent to depart from the explicit constraints upon their authority. Moreover, they will argue that these familiar imstances of deviational discretion are not rightly accounted for either on the supposition that when officials depart from rules they lawlessly usurp legal authority or, on the other hand, that whiat officials do is the real law and what the law says not the law at all.

We will first examine the role of the criminal jury in returning verdicts of acquittal. In the following part we attempt to use the jury discussion to develop some generalized conceptions concerning the nature of deviational discretion. In the succeeding part we explore for other instances of its occurrence in our legal system. The final part attempts to draw some general implications of the phenomenon for legal ordering.

\section{A. The Development of the Criminal Jury}

\section{The Triumph of Jury Power}

In an earlier day juries were leld accountable for their mistakes and misjudgments and their verdicts given effect only so long as they were considered right. The earliest mode of control over jurors was the attaint, whiclr allowed a party against whom the verdict went to 
invoke a larger jury to find the facts anew; if the larger jury found contrary to the first, it could attaint its members-which meant loss of lands, fine, or imprisonment-and reverse its judgment. Though attaints becaine obsolete in the 15th century and, in any event, were apparently little used in criminal cases, another means to control jury error took its place-the judges themselves assumed power to punisli the jurors for incorrect or corrupt verdicts. ${ }^{12}$ Indeed, the practice was formalized by a statute in 1534 authorizing courts to pumish jurors for giving "any untrue Verdict against the King . . . contrary to good and pregnant Evidence ministered to them . . . .13 Apparently, however, in criminal cases, though the jury could be punished for an erroneous acquittal, the prisoner could not, for new trials could not be ordered as they could in civil cases. At all events, the power was used from time to time ${ }^{14}$ until 1670 when Bushell's Case ${ }^{15}$ repudiated the practice and discharged the jurors who had acquitted William Penn of unlawful assembly. The device of ordering a new trial was developed as a substitute means of controlling juries in civil cases. In criminal cases no comparable control evolved.

Froin the end of the 17th century to the present, therefore, the legal power of a jury in criminal cases has been substantial. They render a general verdict, which is to say, they respond with a general finding of guilty or not guilty of the crime charged, both finding the facts and applying the law. ${ }^{18}$ The varieties of special pleading developed in civil cases by which questions of law were separated from questions of fact were never extended to criminal proceedings. When criminal juries convict, a variety of checks and controls operate to assure they act in conformity with the law, including judicial power to set the verdict aside and grant a new trial. But where they acquit there are no such controls. The acquittal is a diktat, a "sovereign power," ${ }^{\text {"17 }}$ for which stated reasons are neitlier expected nor permitted. The jurors may in no way be held to account for their verdict, nor even be made to explain it, nor may they be questioned about it. The verdict is given final and conclusive legal effect, no matter how fully it may be demonstrated that it was contrary to law. As Lord Devlin summarizes it, "Whenever there is a trial by jury, the condenmation must be by a judgment which is both lawful and

12. See generally W. Forsyth, History of TrIAX BY JURY 192-214, 259-98 (1852); P. Devin, Triaz BX JURY (1956).

13. For Jurors in Wales, 26 Hen. 8, c. 4, § 2 (1534).

14. See J. Thayer, A Prelmmnary Treatise on Evidence at the Common LAW 162-78 (1898).

15. 124 Eng. Rep. 1006 (C.P. 1670).

16. Though the jury had the inherent authority to render a special verdict (finding the facts and permitting the judge to find the defendants guilty or not guilty depending on how he should find the law), this practice has fallen into disuse.

17. P. Devin, supra note 12 , at 89. 
the judgment of the country. If his countrymen condemn a man and they exceed the law, he shall go free: if the law condemns him and nevertheless his countrymen acquit, he shall go free."18

\section{The Debate over the Jury's Role}

What did this development mean for the legal authority of the criminal jury to acquit? What is the legal role of the jury with respect to the rules of the criminal law? These questions underlay a classic debate in Enghish and American law. From the end of the 17th century on, the books are filled with controversy over whether the jury in criminal cases had the right to determine the law as well as the facts. The English debate revolved principally around this issue in seditious libel cases: whether the jury should be told that its sole task is to determine if the accused made the publication and not whether the publication constituted criminal libel, which was an issue for the court. ${ }^{19}$

Though technically the controversy was the fairly modest one of whether the criminal jury had the same freedom in libel cases that it had in other criminal cases-to pass on the whole issue through its general verdict-the debates left little doubt that the substance of the controversy centered around the legitimacy of a criminal jury in all cases invoking its own conscience as a bar to conviction. Upon the enactment of Fox's Libel Act in 1792 the narrow issue was resolved in England: in seditious libel, as in all other criminal cases, "the Jury . . . may give a general Verdict of Guilty or Not Guilty upon the whole Matter put in Issue . . . and shall not be required or directed" to find guilt merely on proof of publication. ${ }^{20}$ Whether this was also designed to resolve the larger issue of the legitimacy of jury nullification has been argued both ways. At all events, subsequently in England the issue was never actively pressed and the view came to prevail that the jury's duty is to apply the law given by the court, notwithstanding its power to do otherwise through a general verdict of not guilty. ${ }^{21}$

On this side of the ocean, however, the controversy continued with fresh vigor. The seditious libel issue agaim provoked the debate. The New York trials of John Peter Zenger in $1735^{22}$ and Harry Croswell in $1803,{ }^{23}$ both for seditious libel, produced replays of the judicial de-

18. Id. at $90-91$.

19. See, e.g., Case of the Seven Bishops, 87 Eng. Rep. 136 (K.B. 1688); The King v. Shipley, 99 Eng. Rep. 774 (K.B. 1784); The King v. Withers, 100 Eng. Rep. 657 (K.B. 1789).

20. The Libel Act of $1792,32 \mathrm{Geo} .3$, c. $60, \S 1$.

21. Howe, Juries as Judges of Criminal Law, 52 HARv. L. REv. 582, 583-84

(1939).

22. Trial of Peter Zenger, 17 State Trials 675 (1735).

23. People v. Croswell, 3 Johns. Cas. 337 (N.Y. 1804). 
bates in England. But enactment of laws modeled upon Fox's Libel Act did not, as in England, put the issue to a practical rest. The larger controversy, carried on in the colonies in the 18th century and continued in state and federal courts on through the 19th, was whether the jury in criminal cases should explicitly be recognized as laving the right to determine the issues of law as well as fact, and often implicitly the right to reject the law when they found it unacceptable. The same issue appeared in a variety of guises: Did defense counsel have the right to argue issues of law to the jury in opposition to the view of the law expressed by the judge? ${ }^{24}$ Was it error to instruct the jury in a murder prosecution that they might find a verdict of guilty or not guilty of murder, but that they might not (because the judge found no evidence to justify it) return a verdict of nuanslaughter? ${ }^{25}$ Is it proper to instruct the jury that they are duty bound to follow the instructions of law given by the judge in reaching the general verdict? ${ }^{26}$

These issues produced a number of classic exchanges on the freedoin and obligations of the criminal jury: in New York, between Justice Kent in favor of the jury's right to determine the law and Chief Justice Lewis against it, ${ }^{27}$ in Vermont, between Judge Hall in favor and Judge Bennett opposed; ${ }^{28}$ in Massachusetts, between Justice Thomas in favor and Chief Justice Shaw against; ${ }^{29}$ and in the United States Supreine Court, between Justice Gray in favor and Justice Harlan opposed. ${ }^{30}$

At an early period the view that the criminal jury had the right to determine the law had a widespread vogue. ${ }^{31}$ In some measure this was no doubt attributable to the early American view of the relation of law and democracy - that the official organs of state authority should be sharply curtailed, that the application of the law had always been a powerful weapon in repression, that for the people to govern themselves

24. Commonwealth v. Porter, 51 Mass. (10 Met.) 263 (1845) (yes).

25. Sparf v. United States, 156 U.S. 51 (1895) (no).

26.' United States v. Battiste, 24 F. Cas. 1042 (No. 14,545) (C.C.D. Mass. 1835).

27. People v. Croswell, 3 Johns. Cas. 337 (N.Y. 1804).

28. State v. Croteau, 23 Vt. 14 (1849).

29. Commonwealth v. Anthes, 71 Mass. (5 Gray) 185 (1855).

30. Sparf v. United States, 156 U.S. 51 (1895).

31. The history is related in Howe, supra note 21 , and by the exhaustive najority and dissenting opinions in Sparf v. United States, 156 U.S. 51 (1895). Justice Gray, dissenting, observed:

Until nearly forty years after the adoption of the Constitution of the United States, not a single decision of the highest court of any State, or of auy judge of a court of the United States, has been found, denying the right of the jury upon the general issue in a criminal case to decide, according to their own judgment and consciences, the law involved in that issue-except the two or three cases . . . concerning the constitutionality of a statute.

Id. at 168; see United States v. Moylan, 417 F.2d 1002, $1005-07$ (4th Cir.), cert. denied, 397 U.S. 1064 (1969). 
it was necessary not only that they make the laws but also that they control their administration. As Jefferson wrote, "Were I called upon to decide whether the people had best be omitted in the Legislative or Judiciary department, I would say it is better to leave them out of the Legislature. The execution of the laws is more important than the making them." ${ }^{32}$ Other contributing influences were the sinall difference in legal training, experience, and intelligence between the judge and the jury and the reaction both against the participation of judges in the political and religious persecutions under the Stuarts and against the performance of royal and, later, federalist judges in some of the colomies. ${ }^{33}$

The judicial retreat froin this view began in the 1830's, and by the end of the 19th century the early view had been substantially repudiated. ${ }^{34}$ All that remains are constitutional provisions in the three states - Georgia, Indiana, and Maryland-asserting the right of the jury to judge the law in criminal cases. ${ }^{35}$ But they are by now virtual relics. They have been narrowly interpreted, ${ }^{36}$ grudgingly uplreld ${ }^{37}$ and roundly denounced as "anachronistic," "anomalous," a "blight upon the administration of justice," "archaic, outmoded and atrocious," "unique and indefensible."38

Behind this prevailing view of the jury's duties stands the ideal of the rule of law, with which a jury's right to take law into its own hands is wholly imcoinpatible. ${ }^{39}$ To recognize such freedom in a jury would risk an intolerable uncertainty as the law shifted from case to case depending upon the cliance make-up of the jury. Moreover, to do so would invite any group of twelve to abrogate a law duly enacted by the legislature on the basis of their own views of what the law should be. Protection against bad laws should not come through the nullification of democratically enacted legislation by any dozen jurors, but through the democratic processes for changing the law.

32. Letter from Jefferson to L'Abbé Armond, July 19, 1789, in 35 WrITINGS of Thomas JefFerson 104 (P. Ford ed. 1895).

33. Untted States National COMM'N on LaW ObServance and ENForcement, Report on CrimINal Procedure No. 8, at 27 (1931).

34. Howe, supra note 21; Sparf v. United States, 156 U.S. 51, 168 (1895) (Gray J., dissenting).

35. GA. Const. art. I, § 2-201; IND. Const. art. I, § 19; MD. Const. art. XV, § 5.

36. Rouse v. State, 136 Ga. 356, 71 S.E. 667 (1911); Beavers v. State, 236 Ind. 549, 141 N.E.2d 118 (1957); Bridgewater v. State, 153 Ind. 560, 566, 55 N.E. 737, 739 (1899); Giles v. State, 229 Md. 370, 183 A.2d 359 (1962).

37. Wyley v. Warden, 372 F.2d 742 (4th Cir. 1967).

38. See id. at 745.

39. See, e.g., United States v. Battiste, 24 F. Cas. 1042, 1043 (No. 14,545) (C.C.D. Mass. 1835) (Story, J.); Commonwealth v. Porter, 51 Mass. (10 Met.) 263, 280 (1845) (Shaw, C.J.); W. ForsYTH, supra note 12, at 261. 
In recent days the rising moral repugnance to the Vietnam war and to the laws supporting it, such as the draft, have led lawyers to renew the old argument that the jury should be told they are free to disregard the court's instructions and that the lawyers should be permitted to argue to the jury that they should do so. ${ }^{40}$ But the old tradition is apparently too long dead to be revived. As the Fourth Circuit recently held, quoting the words of a Supreme Court opinion at the turn of the century: "We must hold firmly to the doctrine that in the courts of the United States it is the duty of juries in criminal cases to take the law from the court, and apply that law to the facts as they find them to be from the evidence." "41 A representative standard instruction on the duty of the jury is: "It is my duty to instruct you in the law that applies to this case, and you must follow the law as I state it to you." 42

\section{The Persistence of the Issue}

The triumph of the restrictive view of the jury's competence in the formulations of the courts, however, has by no means cleared the air of uncertamty and ambiguity concerning the jury's role in acquittals. The setting and context in which the judge instructs the jury on its duty must also be considered if the conscientious juror is properly to understand what he is truly to do and not to do. And that setting and context as it exists today tends im a number of respects to cloud the clarity of the judge's injunction to the jury to follow the law as he states it.

a. Power and right. The criminal jury has evolved, not accidentally as we have seen, to where it exercises a "sovereign" power in criminal cases. The power to return a general verdict cannot be taken from it. It returns its verdict without stated reasons or justifications of any kind. If it finds the defendant not guilty, the acquittal must be given final and binding legal effect, no matter what may be thought or known about the jury's failure to follow the law. And the jury itself is fully insulated froin any accountability for its action.

In these circumstances Alexander Hamilton's argument has to be fairly faced: "All the cases agree that the jury have the power to decide the law as well as the fact; and if the law gives them the power, it gives them the right also. Power and right are convertible terms, when the law authorizes the doing of an act which shall be final, and for the

40. See United States v. Moylan, 417 F.2d 1002, 1005, (4th Cir.), cert. denied, 397 U.S. 1064 (1969); United States v. Sisson, 294 F. Supp. 520, 523 (D. Mass. 1968); Sax, Conscience and Anarchy: The Prosecution of War Resisters, 57 YALE ReVIEw 481 (1968); Van Dyke, The Jury as a Political Institution, 16 CATH. LAWYer 224 (1970).

41. United States v. Moylan, 417 F.2d 1002, 1007 (4th Cir.), cert. denied, 397 U.S. 1064 (1969), quoting Sparf v. United States, 156 U.S. 51, 101-02 (1895).

42. Cal. Jury Instructions-Criminal, CALJIC 1.00, at 2 (1970). 
doing of which the agent is not responsible." ${ }^{\prime 3}$ He was not arguing that there should be no constraints upon the jury in the way it exercises its power. His point was that the legal right followed from the legal power. ${ }^{44}$ Judge Kent, accepting Hamilton's argument, put it this way: "The law must . . . have intended, in granting this power to a jury, to grant them a lawful and rightful power, or it would have provided a remedy against the undue exercise of it. The true criterion of a legal power is its capacity to produce a definitive effect, liable neither to censure nor review. And the verdict of not guilty, in a criminal case, is, in every respect, absolutely final. The jury are not liable to punishment, nor the verdict to control."

b. Courts and jury. The force of these propositions is enhanced by what the courts have said and done in dealing with specific legal issues concerning the criminal jury. When a judge hears a criminal case without a jury and finds the defendant guilty of one charge and not guilty of another in circumstances in which such finding is illogical and inconsistent, the judgment of guilt is reversible, on the ground that there can be no confidence in the correctness of that judgment. ${ }^{46}$ But where a jury returns verdicts that are no less inconsistent and illogical, the guilty verdict is regarded as irreversible. In a leading case so holding, ${ }^{47}$ Justice Holmes referred to his own earlier dictum that "the jury has the power to bring in a verdict in the teeth of both law and facts," quoted with approval froin Learned Hand, who liad observed in a comparable situation: "We interpret the acquittal as no more than their assumption of a power which they liad no right to exercise, but to which they were disposed through lenity." 49 The nature of their lack of "right" is put into context by a subsequent observation of Judge Hand:

The institution of trial by jury-especially in criminal cases-has its hold upon public favor chiefly for two reasons. The individual can forfeit his liberty-to say nothing of his life-only at the hands of those who, unlike any official, are in no wise accountable, directly or

43. People v. Croswell, 3 Johns. Cas. 337, 345 (N.Y. 1804).

1964):

44. I THe LAW PRActice OF AlEXANDER HaMilton 828-29 (J. Goebel ed.

Can the Jury do it with power, and without right? When we say of any forum that it can do, and may hazard the doing a thing, we admit the legal power to do it. What is meant by the word hazard? if they choose to do it, they have then the legal right. For legal power includes the legal right. This is really only a question of words. But in the exercise of this right moral ideas are no doubt to restrain, for the conscience ought to decide between the charge, and the evidence which ought to prevail; one side or the other.

45. People v. Croswell, 3 Johns. Cas. 337, 368 (N.Y. 1804); see Sparf v. Urited States, 156 U.S. 51, 173 (1895) (Gray, J., dissenting).

46. United States v. Maybury, 274 F.2d 899 (2d Cir. 1959).

47. Dunn v. United States, 284 U.S. 390 (1932).

48. Horning v. District of Columbia, 254 U.S. 135, 138 (1920).

49. Steckler v. United States, 7 F.2d 59, 60 (2d Cir. 1925). 
indirectly, for what they do, and who at once separate and melt anonymously in the commumity from which they came. Moreover, since if they acquit their verdict is final, no one is likely to suffer of whose conduct they do not morally disapprove; and this introduces a slack into the enforceinent of law, tempering its rigor by the inollifying influence of current ethical conventions. ${ }^{50}$

In civil cases tried before a jury the use of special interrogatories formulated by the court to assist the jury in arriving at their general verdict logically and according to the legal instructions is long accepted and quite common. So is the special verdict, in which the jury is instructed to return only a special verdict in the form of a special written finding upon each issue of fact, leaving it for the court to enter judgment in accordance with the law as applied to the jury-found facts. ${ }^{51}$ Both devices serve as controls on the jury, functioning to assure judgments in accordance with the law.

At the common law there is authority for the use of such devices in criminal cases as well, although the jury could always decline and insist on returning a general verdict. ${ }^{52}$ However, such devices have been even inore rarely used in this country than in England, and current authority finds them in violation of the right to trial by jury. An instructive case is United States $v$. Spock, ${ }^{53}$ in which the court reversed a conviction of conspiracy to counsel evasion of the draft. The trial court had put to the jury, in addition to the general issue of guilty or not guilty, ten special questions calling for a yes or no answer. This was enough to require reversal of the conviction, even assuming the correctness of the questions proposed. The right to jury trial, the appellate court reasoned, would be meaningless if the jury were not free from judicial pressure. The prohibited directed verdict of guilty is the most direct of such pressures. But lesser and more indirect pressures, sucli as the requirement of a special verdict or the use of special interrogatories, are impermissible for the same reason. In explanation, the court quoted the following excerpt from an earher decision:

To ask the jury special questions might be said to infringe on its power to deliberate free from legal fetters; on its power to arrive at a general verdict without having to support it by reasons or by a report of its deliberations; and on its power to follow or not to follow the instructions of the court. Moreover, any abridgment or modification of this institution would partly restrict its historic function, that of

50. United States ex rel. McCann y. Adams, 126 F.2d 774, 775-76 (2d Cir. 1942).

51. E.g., Fed. R. Civ. P. 49.

52. United States v. Ogull, 149 F. Supp. 272 (S.D.N.Y. 1957).

53. 416 F.2d 165 (3d Cir. 1969). 
tempering rules of law by common sense brought to bear upon the facts of the case. ${ }^{54}$

The court went on to say that the fact the questions were proper in substance and therefore helpful in producing a logical and consistent apphication of the law would not be a sufficient reason for condoning the practice, quoting Learned Hand's statement:

I should like to subject a verdict, as narrowly as was practical, to a review which should make it in fact, what we very elaborately pretend that it should be: a decision based upon the law. In criminal prosecutions there may be, and in iny judgment there are, other considerations which intervene to make such an attempt undesirable..$^{55}$

And, "Uppermost of these considerations," said the court, "is the principle that the jury, as the conscience of the community, must be permitted to look at more than logic."56

Of substantial relevance also in seeking illumination on the role of the jury is the basis on which the Supreme Court has held the right to trial by jury protected by the due process clause of the fourteenth amendment. It has recently done so by recognizing the jury's power to displace law by appeal to conscience as one of the very characteristics which gives it its fundamental importance-so "fundamental to our system of justice" ${ }^{97}$ that a state violates due process of law in eliminating jury trial. Not only is the jury the historical "safeguard against the corrupt or overzealous prosecutor and against the compliant, biased or eccentric judge," $" 58$ but in differing from the law-bound conclusions that judges would reach, they serve "some of the very purposes for which they were created and for which they are now employed."59 In other words, the fundamental function of the jury is not only to guard against official departures from the rules of law, but, on proper occasions, to depart froin unjust rules or their unjust application. Even Justice Harlan, in dissent, conceded one of the virtues of the criminal jury to be that "[i]t eases the burden on judges by enabling them to share a part of their sometimes awesome responsibility." ${ }^{300}$ Whatever doubt there might be about what he had in mind is resolved in his footnote reference to Benjamin Curtis' observation: "Juries relieve the judge of the embarrassment of making the necessary exceptions. They do this, it is true, by violating

54. Id. at 181, quoting United States v. Ogull, 149 F. Supp. 272, 276 (S.D.N.Y. 1957).

55. 416 F.2d at 182, quoting Skidmore v. Baltimore \& O. Ry., 167 F.2d 54, 70 (2d

Cir. 1948) (L. Hand, J.).

56. 416 F.2d at 182.

57. Duncan v. Louisiana, 391 U.S. 145, 153 (1968).

58. Id. at 156 .

59. Id. at 157 .

60. Id. at 187 . 
their oaths, but this is better than tempting the judge to violate his oath of office." $"$ 1

c. Jury tradition. The jury's obligations and freedoms are determined by tradition as well as law. The landmark cases, particularly those involving criminal libel and sedition, in which the jury invoked its power to nullify what were widely regarded as unjust laws, are invoked not as regrettable departures from the rule of law, but as historic and seminal acts, like Magna Carta and the Bill of Rights, by which men asserted their right to be free of unjust laws. Arguments in support of the fundamental value of the jury almost always rest on the nullifying function of criminal juries. Dean Pound, for example, observed: "Jury lawlessness is the great corrective of law in its actual administration. The will of the state at large imposed on a reluctant community, the will of a majority imposed on a vigorous and determined minority, find the same obstacle in the local jury that formerly confronted kings and ministers." tied pretty closely to the law; the law may be made as flexible as possible, but the justice of the case cannot go beyond the furthest point to which the law can be stretched. Trial by jury is a unique institution, devised deliberately or accidentally-that is, its origin is accidental and its retention deliberate-to enable justice to go beyond that point." ${ }^{\text {"33 }}$ Nor is it only "a protection against tyranny. It is that: but it is also an insurance that the criminal law will conform to the ordinary man's idea of what is fair and just. If it does not, the jury will not be a party to its enforcenrent." 64

d. Jury behavior. There is ample evidence of the continuity of the tradition of jury nullification of unjust laws. The classic historical instances include the jury's refusal to convict in a number of famous cases of criminal libel until the law was changed to give juries the authority to acquit through general verdicts, ${ }^{65}$ and the strategies of early English juries in avoiding capital pumishment, such as finding against the evidence that only 39 shillings had been stolen when to find 40 shillings or more meant a mandatory death sentence. ${ }^{68}$ Later, in this country,

61. Curtis, The Trial Judge and the Jury, 5 VAND. L. Rev. 150, 157 (1952). Unlike the majority, however, Justice Harlan had some reservations: "A jury may, at times, afford a higher justice by refusing to enforce harsh laws (although it necessarily does so haphazardly, raising the questions whether arbitrary enforcement of harsh laws is better than total enforcement, and whether the jury system is to be defended on the grounds that jurors sometimes disobey their oaths)." 391 U.S. at 187.

62. Pound, Law in Books and Law in Action, 44 AM. L. Rev. 12, 18 (1910).

63. Devlin, supra note 12, at 154.

64. Id. at 160 .

65. E.g., The Libel Act of 1792,32 Geo. 3, c. $60, \S 1$; see text accompanying notes 19-23 supra.

66. House of Commons Select Committee on Capital Punishment, Report 
we have witnessed the American jury's systematic nullification of the Prohibition laws during the 1920 's-_ 'the most intense example of jury revolt in recent history." ${ }^{\text {"67 }}$ More recent data has been added by Professors Kalven and Zeisel. Their study of the American jury demonstrated the more subtle use of the power by contemporary American juries. Of the 3,500 sample trials reported on, about 19 percent were cases in which the jury acquitted where the judge convicted. In examining the various reasons for judge-jury disagreements, the authors determined that "jury sentiments on the law" accounted for or contributed to half of all the disagreements. Of that half, twice as many disagreements were attributable to disagreements caused by a combination of "facts and values" than were attributable to values (jury sentiments on the law) alone. This revealed, they concluded, "the salient role played by jury sentiments on the law in causing disagreements; jury equity looms as a significant factor." 88 They further identified the importance of evidentiary determinations as the principle vehicle for the contemporary jury to infuse their own values into their verdicts: "We know . . . that the jury does not often consciously and explicitly yield to sentiment in the teeth of the law. Rather it yields to sentiment in the apparent process of resolving doubts as to evidence. The jury, therefore, is able to conduct its revolt froin the law within the etiquette of resolving issues of fact." ${ }^{\text {"9 }}$,

The jury's "revolt from the law," the authors noted, is a modest one at present, reflecting a general acceptance of the substantive criminal law. They saw it manifesting itself "as a moderate corrective against undue prosecutions for gambling, game, and liquor violations and, to some extent, drunken driving." ors' rejection of particular rules of the criminal law that they felt inappropriate, such as the "nice" legal obstacles to the privilege of self defense, the legal irrelevancy of the contributory fault of the victim, and the extent to which the defendant had already suffered. ${ }^{71}$

\section{B. Interpreting the Jury's Role}

\section{The Conventional Interpretations}

If, now, the juror is obliged to do as he is instructed by the court, and if he may, nevertheless, do as he thinks best-if, in fact, he is af-

viii-ix (1931); see 1 L. Radzinowicz, A History of English CrIminal Law and Its ADMINISTRATION FROM 1750, at pts. IV-V (1948).

67. H. Kalven \& H. ZeIseI, The AMERICAN JURY 291 (1966).

68. Id. at 115 .

69. Id. at 165 .

70. Id. at 296.

71. See id. at $492-99$. 
forded every protection that will make it possible for him to do as he thinks best and his function as a juror is extolled because jurors sometimes do-how is the conscientious juror to understand his role? What is he to do in his jural role if it seems to him that to follow the court instructions would lead to a verdict he is convinced ought to go otherwise?

The question appears puzzling on the common and not implausible assumption that the law must present itself to its agents in a umvocal sense, that a proper understanding of what the law requires of an agent in any one respect will reveal a single, consistent directive fixing the agent's duty and, so far as the law cxtends, leaving nothing up to him. Therefore, in order to interpret the jury's role in acquittals, we shall comment on each of the two possible positions which, making the assumption of the single, consistent directive, hold that the duty of the juror to comply with court instructions is logically incompatible with the privilege of the juror to do as he thinks best, and that the legal systein itself may have it one way or the other, but not both. Then we shall try to read the jury situation in acquittals on the hypothesis that the dilemma between duty and privilege is a false one for the legal system and show how and in what sense.

a. Interpretation 1: The jury's role is to follow the court's instructions. According to this first way of understanding the situation, official formulations fully state the proper role of the jury: the jury is strictly a fact-finding agency. It reaches its general verdict by applying facts found in accordance with the judge's legal instructions. Its own sentiments concerning the law, either generally or as applied to the case before it, are of no consequence. Of no consequence also is the jury's estimate of the force of any mitigating circumstance not comprehended in the law, or of its own conception of the nature of the law if it differs from the judge's. The vaunted "sovereignty" of the jury, therefore, is a matter of power, not of right. We often have the power to do things we have no right to do. The jury can reach a perverse verdict of acquittal and get away with it, but that does not imply the right to reach such a verdict. When juries do so, when they reach verdicts that run counter to the expressed instructions of the court, they usurp a discretion not theirs to exercise. That jury nullification has sometimes produced good results does not show that nullification is within its legal role.

Such is one construal of the jury's role. The technique is to acknowledge an inconsistency between jury power and jury duty in cases of acquittal, assume that the inconsistency cannot be, and then explain away the class of evidence that points to jury privilege. Yet why, except that one has just made an independent choice among competing values and decided it a good thing to have the jury do as it is told, may one 
not equally well follow Alexander Hamilton and discover in the scrupulous protection of jury power the institution of a "sovereign" right? There is nothing logically wrong with the finding of "sovereignty." The question is how to construe the jury power to reach a "perverse" verdict of acquittal. Even in ordinary inatters, when people are systematically protected not inerely against incursions into their power to act as they think best, but also against any attempt to hold thein accountable for an alleged misuse of that power, they begin to get the message: they have the right to act as they think best, whether or not they made the right decision. And if anyone tries to call them to account for a wrong decision, they do not simply accept the criticisin as arguable-they are outraged. Why should the adherents of Interpretation 1 not apply similar reasoning to juries if it were not that for jury decisions they want it otherwise?

b. Interpretation 2: The jury's role is to follow the law-in-action. One use of Pound's farnous distinction between "Iaw-in-action" and the "law-in-books"72 is to make plausible the assumption of a single, consistent directive defining the jury role in precisely the reverse sense of Interpretation 1. Instead of arguing that the role of the jury demands following the instructions of the judge, one holds that the instructions of the judge constitute only the formal law, but that the real law, the lawin-action, leavcs it to the jury to follow the instructions of the judge only when so inclined. To be sure, there is a real question what Pound and others who have adopted the distinction inean by the law-in-action. Sometimes, they seein to mean that the law-in-action is, flatly, what people in authority do, their actual behavior independently of any formulable rule. In that sense, of course, the law-in-action lays down no requirement upon juries at all: whatever they succeed in getting away with is the law-in-action. At other times the distinction serves to set off the actual norms of the pohtical-legal coinununity against the norms announced in the books and disregarded in the practice. It is in that second sense, we are proposing, that the realist distinction shores up a rule of competence for the jury: "Do as you think best. Take or leave the court's.instructions." Any jury that thought itself bound to the court's instructions would then have misunderstood its own role. The mconsistency between duty and privilege has been overcome: the duty is merely formal; the privilege is real in the law.

But even if Interpretation 2 should rest on the law-in-action in this latter sense-that is, on the basis of a determination of what the real, rather than apparent norms of the law may be- the question of how to determine the real norm remains. We propose that there is no direct

72. Pound, supra note 62. 
inference from the law-in-action to the real norm of jury sovereignty postulated in Interpretation 2 without the addition of an independent preference for that condition. In the face of the history of the jury acquittal, Interpretation 2, like Interpretation 1 , needs a normative principle to select one part of the evidence rather than the other as determinative.

The principle is necessary because for the law-in-action to be the law in action, it must be possible for actual behavior to count as a transgression, even if the transgressor be an official. What actual behavior cannot violate can constitute no rule. How then, in view of the tortured trajectories of human actions, are we to argue to the real, binding rule? Which class of behavior represents compliance with the actual norm, which a misguided attempt to follow merely fictitious ones: the behavior of deferring to the judge's instructions or the behavior of defying them? When, in effect, does the jury deviate from the law-inaction, and when does it not? To ascribe to the jury a determinate role at all implies that the jury might deviate from the law-in-action. Why do the statistically far more numerous imstances of compliance with court instructions carry so much less weight in determining the law-imaction than the far fewer instances of departure? Why should the fact of jury impumity be granted all possible weight? Such questions seem readily answerable only if one takes a preference for one sort of jury behavior over another to determine what the law-in-action actually is. Behavior will satisfy the law-in-action that fulfills presumably valuable functions, while behavior grounded on formal obligations that fulfill no such functions become misguided attempts to satisfy the law-in-books.

Moreover, even if the jury's role is indeed to follow the law-in-action and that law is determinable (by a proper judgment of value), there remains much that the practitioners of the legal profession consider law that goes systematically ignored. It remains a fact that jurors are obliged to take an oath to decide the case according to the law and the evidence. The judge does instruct the jurors in the applicable law and direct them to arrive at their verdicts in accordance with it. The lawyer for the defendant may not argue to the jury that the law is otherwise than as stated by the judge or that they should disregard the law in any event. So, at the very least, the jury cannot be said to have the right to invoke its own sentiments on what the law should be in the sense that an official has the right when the law delegates to him an explicit discretionary authority to do so.

In short, the logical source of the radical oversimplifications of Interpretation 1 and Interpretation 2 alike is the notion that the law has to speak to the jury in one consistent voice. It is that assumption that leads the proponents of these interpretations covertly to introduce a normative primciple so that the notion of the single, consistent directive 
can work. That assumption makes it necessary to argue that, in considering whether to acquit, either the jury has an obligation as jury to follow the instructions of the court or that the jury has the power and a derivative right not to follow the instructions of the court, but not both.

\section{An Alternative Interpretation: The Jury's Role as Conflicted}

Now we submit that logic does not prohibit an interpretation of the jury's role under the law as both requiring conformity to the instructions of the court and extending at least the privilege to return a general verdict of acquittal contrary to those instructions. What prohibits such an interpretation is only the notion of the single, consistent directive, which presumes that it is one and the same agency, one and the same voice, that speaks to the jury. It is as though one were to imagine a judge saying, simultaneously, "Follow my instructions; it is your duty," and, "Use your own judgment." One could fairly conclude that such a judge did not know what he wanted; no guidance whatsoever could be conceived to come from him. And so it would be for the law as a whole, if one conceived its directives and privileges to issue from the selfsame mouth, for the same subject and subject matter, in the same respect. Plainly, any single sovereign had better be consistent.

On the other hand, if one does not confuse a theory of the way legal judgments derive legitimacy with the structure of the law and the way it impacts on persons acting in legally defined roles, the notion of a consistent directive of a single sovereign loses its apparent necessity. It is, after all, false that the judge says, "Follow my instructions," and, "Use your judgment." He says only, "Follow my instructions." Other arrangements in the legal system convey a genuine privilege not to do so. The juror, if he listens, hears many voices, some issuing from real bodies, others issuing from traditions and ways of proceeding. Indeed, the law may be conceived as the totality of these voices. But whether so conceived or not, it remains true that a variety of claims and dispensations focus upon the man in the jury box. He is told what he ought to do-and yet he need not do it and is protected agamst any consequence of not doing so. His role is conflicted in the sense that there is conflict in the authoritative rules governing his competence in his.role. Judgment is thrust upon him, not inerely of the guilt or innocence of the defendant, but of the merit of the judge's instructions for the particular case. He is told what the law is, authoritatively; he is obliged; and then he is told to reach his decision, he and he alone, immune from consequence, the verdict of acquittal safe from overturning. He has become the final judge whether or not to uphold his obligation.

How is this kind of role possible? How can the law distinguish a conflicted role such as the jury's from a role that is simply hung-up, in 
the sense that the agents of that role have no way of deciding among the various messages that they receive? There is nothing arcane about the matter at all, we think, and for these reasons:

First, all roles, in the sense in which we have been using the term, are set up to perform certain jobs for certain ends and in certain prescribed ways according to certain procedures and constraints. So the jury has been set up to reach judgments of guilt or innocence for the sake of the ends of criminal justice according to certain procedures and constraints that number among them the instructions of the court. From this there arises both the crucial problem of conflicted roles and the possibility of a solution. For while the means to securing the role's end bind those who seek the end in the role, those means may from time to time prevent the role agent from achieving his role's ends. That is the problem. But a solution is provided if the role has been set up, as has the jury role, to allow the role agent to consider the ends for which he accepts its constraints. The role agent evaluates the actual consequences of remaining faithful to the estabhished means of the role in terms of the ends souglit to be achieved. The jury considers whether literal applications of the court's instructions will advance or impede the goals of criminal justice. So the conflicted role, in contrast to the hung-up role, makes available to the agent a system of ends that enable him to judge. the applicability of his obligations and insures that he may act upon that judgment. If the conflict occurs among the ends of the role itself rather than simply between some prescribed means and some end or ends, the principle is similar: The agent has available the role's whole organization of means and ends on which to make a judgment on which end or ends shall prevail and which yield.

Second, judgment by a role agent of any of his obligations is made possible, and the transition from a liung-up role to a conflicted one achieved, because the reality of an obligation is not necessarily denied when the obligation is held as something less than absolute. It is on this ground that we say that the instructions of the judge are binding on the jury and, at the same time, that the criminal jury may judge its obligation in relation to the particular case. Because the jury's role exacts from the conscientious juryman the distinction between departing from an instruction because lie thinks it preferable (thereby ceasing to treat the mstruction as obligatory) and departing from an instruction because he has "damn good reason" to do so as determined by the role ends, the jury acquittal role retains the obligatory status of the imstruction while permitting a departure from that instruction. For, in general, we recognize a constraint as obligatory upon us when we require not merely reason to defend our rule departures, but damn good reason.

It may be objected that we can rid ourselves of the notion of a con- 
flicted role and preserve a single, consistent directive simply by recognizing the actual rule that defines the role of the acquitting jury to be a conditional: "If you don't have good reason-damn good reason-then do what the judge tells you." The current formulation of the judge's instructions to the jury is misleading - and has misled us. The proposed conditional expresses the meaming of the struggle between jury freedom and the judge's authority.

But this argument falls short for several reasons. The conditional formulation is spurious if its intent is really to restate the conditions met by the idea of a conflicted role as a single, consistent directive that in itself generates no conflict but is either obeyed or disobeyed. Privileges can always be stated to qualify obligations, but the achievement does not diminish either the privilege or the obligation. Any juror hearing the above conditional would know immediately that lie faced no less an obligation for the fact that it was not universally overriding; precisely that, le would understand, was the point of the demand for "damn good reason." Regardless of whether the juror translated the conditional message into the language of privilege and obligation, he would face the same consequences: that the choice whether to obey the instructions of the judge had been thrown back upon him; that he would, finally, not escape a judgment on what obligations would bind him in the instant case and what not; that he would need to find reasons of overriding weight.

Further, the "damn good reason" in the conditional we have posed conditions jury action on some ultimate norm or norms of the legal system or of morality in general, and is only poorly understood when assimilated with other, rather simpler conditions. "Do as the judge tells you unless the consequence is serious injustice," differs in important respects from, "Assign applicants to windows according to their last names, unless the line exceeds ten persons." First, there exists no routine for saying what "serious injustice" means, as there does for determining the number of people on a line. Indeed, that is just why the juror in our conditional is told to consider whether a "serious injustice" may be done: because there is no telling him precisely what it means. If there were an adequate routine for doing so, very likely it would be provided and the juror's situation would indeed become rather like the clerk's in determining whom to assign to a window. Secondly, the two sorts of conditional are unlike because there can be no question of being pulled between assigning people with certain last names to lines and the results of counting persons on line, as there can be between the demand to obey the authoritative instruction of the court and, at the same time, the legal or moral requirement to pursue the ultimate end of judgment, which is justice. So it simply will not do, as the assumption of the conditional directive requires, to treat the introduction of an ultimate 
end into the deliberations as though one had merely introduced another condition in a conditional directive for attaining soine end, and procured thereby a directive that left it to the receiver of the law only to coinply or not.

In sum, then, the case for characterizing the role of the jury as a conflicted role turns on the following propositions. First, logical necessities do not prohibit such a role, nor does an easy reformulation make such a role disposable. Next, conflicted roles like that of the jury are functional; they perform distinct uses in the administration of justice. Lastly, this characterization of the role of the jury accommodates the apparently divergent themes presented by the evidence. It does not require, as alternative interpretations do, that portions of the evidence be oversimplified or explained away.

So characterizing the role of the jury as conflicted allows us to say the following: The duty of the jury is indeed to find the facts upon the basis of the evidence presented and to issue a general verdict by applying those facts to the propositions of law given by the judge. This is the rule, and it imposes an obligation to comply. But it is not therefore an absolute and unyielding obligation. For sometimes the jury's perception of what common sense requires, or considerations of fairness to the defendant, or the jury's appraisal of the law in contradistinction to the judge's statement of it may weigh so heavily that they justify the jury's departure from the requirement that it defer to the instructions of the judge; and that justification may be not merely in the mind of the juror (it may not be in his mind at all), but in the structure of the legal system.

But perhaps it will be useful to pause a moinent and coinment on proposals that certain information deliberately be put into the minds of the jurors: that jurors be told by the court that, despite judicial instructions on the law, they are free to acquit if they find the law unjust in its application to the defendant. ${ }^{73}$ Plainly the question of how judges might best formulate their instructions to criminal juries is a different question from how jurors are to read their obhgations undcr the legal system as it stands. Nonetheless, what we have said about the jury's conflicted role under existing arrangements has some bearing.

One good reason for not telling the jury that they are free to ignore the instructions of the court when the application of those instructions would lead to a conviction of which they disapprove is that jurors are in fact, under present legal arrangeinents, not free in this sense. So to instruct them is to adopt the interpretation of the role of the jury identified earher with Interpretation 2 and therefore to change the nature of the

73. See note 40 supra. 
jury's role. The force of the juror's oath and the settled legal view that jurors are obliged to apply the law given them to the facts serve to confine the implied privilege to depart to the genuinely exceptional case where there is overriding and compelling reason to invoke that privilege.

An alternative instruction might, of course, put it to the jurors that they are obliged to follow the court's instructions on the law except in truly exceptional cases where, as it miglit be said, in good conscience they find it repugnant to do so. As noted earlier, this formulation would not differ substantively from the obligation derivable from existing arrangements. With the privilege expressly stated, the role of the jury would be no less conflicted. In view of the ultimate-ended character of the privileging conditions, the clroice would still be whether to depart from an obligation by force of an appeal to the final ends of the role. Yet whether the jury should be expressly so told or left to deduce it is another question. The gains are plain enough: an assurance that some juries would not be misled, with the consequent advantage of ensuring that the social benefit of such dispensation would be available in every cases and equality assured in the treatinent of defendants. But there would be costs to be reckoned as well.

The very technique of explicitly instructing the jury, without qualification, that jurors are obliged to apply the law given by the courteven though they are protected in their power to do otherwise-serves to raise the ante on the jury substituting its own evaluations. One of the interesting conclusions reached by Kalven and Zeisel in their study of the behavior of the criminal jury was that while the jury does in fact make use of its power to follow its own sentiments, it does not deviate from the judge very often; the jury is not, as they say, "a wildcat operation." And this is so, they observe, not only because there is presently no great gap between official and popular values in criminal cases, but also because the jury "has been invested with a public task, brought under the influence of a judge, and put to work in solemn surroundings." And, they conclude, "Perhaps one reason why the jury exercises its very real power so sparingly is because it is officially told that it has none."

To the extent this is so, an explicit formulation that they may invoke their own values, even if put in terms of the highly exceptional case, would reduce the felt weight of the court's instructions and invite jury nullification on a greater scale. Whether this is desirable or not is another matter. Choice turns on the value placed on jury nullification in particular stages of a legal system's development as against the increase of arbitrary variability of verdicts and of removing the criminal

74. H. Kalven \& H. ZeISEI, supra note 67, at 498.

75. Id. 
law still further from the control of court and legislature. Our task is not to argue the issue but simply to show that there is one.

\section{III}

\section{THE CONCEPT OF LEGITIMATED INTERPOSITION}

We may use our analysis of the conflicted role of the jury to formulate a general conception for instances in which the official's role provides for the possibility of justifying, under the law, departures from the rules of competence that bind him. In contrast to the concept of delegated discretion, which denotes an explicitly delegated legal power to act according to an agent's best judgment within defined limits, but in contrast also to the conception of usurpation, whicls entails an exercise of power im outright defiance of the legal system, we propose the concept of legitimated interposition to cover instances comparable to that of the acquitting jury where a deviational discretion becomes embedded in legal arrangements. "[T] tice White for the Court, "obviously lies in the interposition between the accused and his accuser of the common sense judgment of a group of laymen, and in the community participation and shared responsibility which results from that group's determination of guilt or innocence."70 The concept of legitimated interposition generalizes the phenomenon to which Justice White has pointed and for which we have attempted to account. Actions are legitimated for a role agent insofar as the role justifies his undertaking such an action. When a legal system presents an official with the freedom to depart from a legal rule that might work counter to the ends of his role, this legitimates the official's departure from the rule. It legitimates the interposition between the rule and his final action of his own judgment that departure from the rule best serves the end.

For the most part, a legal system has been conceived to work independently of any set of principles for the adjustment of its rules to the requirements of its agents' roles. But we believe it false that the only possible relation of agents in a legal system is, simply, to hear and obey, and imtroduce legitimated interposition in order to discuss the possibility of such an adjustment.

\section{A. The Conditions of Legitimated Interposition}

Generalizing from the instance of the acquitting jury, we may determine what characteristics of the legal system tend to support a reading of the official's role that justifies his departure from a rule defining and

76. Williams v. Florida, 399 U.S. 78, 100 (1970). 
limiting his competence. We may say, first, that legitimated interposition requires that the official be given authority to effect legal consequences greater than that permitted by the rules defining his competence and that, in one way or another, the system recognize the exercise of this power to produce those consequences with formal or practical finality. That is, a legal power is granted to effect legal consequences without recourse against either the action or the official.

Yet it seems to us that this is not and cannot be all, if legitimation of a rule departure by an official is to have the force of a justified act. That an act and its agent are both unchallengeable may prove only the lainentable shortcomings of the systein and confirm the truth of Lord Acton's dictum that all power tends to corrupt and absolute power absolutely. If there is to be legitimation at all, therefore, the system must set up and make available to the agent who proposes to depart from a rule some set of ends in virtue of which the act of departure from a rule might truly be justified. The act of interposition must be shown to be the kind of act, at least on the whole, that has positive value for the legal system. For it is not the juryman's vote contrary to the judge's instructions as a consequence of a bribe that is legitimated; it is the juryman's vote as an essay, however mistaken, in the direction of justice, which, unlike the financial improvement of the juror, is indeed an objective of the legal system. This condition holds wherever legal systems are held to legitimate rule departures, and, together with a power to effect legal consequences without recourse against the action or the official, establishes the presence of legitimated interposition.

But when this second condition obtains, when we have a rule departure legitimated rather than an act of arbitrary power facilitated and protected, is hardly self-evident. The relevant considerations are the extent to which a class of official deviation from rules is widely acknowledged, rationalized, and built upon, serves purposes consonant with those of the legal system, and has become a domesticated and integrally functioning instrument of its exercise. Involved in determining that rule departures serve purposes consonant with those of the legal system is a reading of a complex and subtle interplay of rules, practices, and arrangements and of the underlying purposes achieved and missed. We have tried to show in the case of the jury what this might mean concretely.

\section{B. The Possibility of a Justified Rule Departure}

At this point we must meet a possible objection, one not ostensibly aimed against the notion of a conflicted role (like the jury role in acquittals), but against the coherence of the idea of a legally justified departure froin a legal rule. How could there be a legally justified departure 
from a legal rule unless the rule departed from were not, actually, a legal rule of the system? If a citizen breaks a rule, appeals, and wins against the rule, do we not commonly say that the rule was unconstitutional and hence not a rule of the legal system? If an official ignores the rule of competence that binds him in a certain way in the exertion of his legal power and it turns out that his action was legally justified, ought we not to say that the rule of competence in question was thought to be a rule but has been demonstrated not to be?

At issue is the desirability of post hoc explanations of legal phenomena. To answer a question about how a system secures its results, one states the characteristics of the results. In this way the system becomes the cause of its own development, its characteristics are conceived as formed $a b$ initio, and departures from the system's rules, once legitimated, lose the character of departures from rules that they possessed in the process of decision. The statute under which the defendant was penalized, having turned out to be unconstitutional, was never the law. ${ }^{77}$ The court instruction that the jury disregarded was never obligatory in the process of the jury's decision because the jury decision which deviated from the instruction was sustained in the ways we discussed earlier. The church never changes; the truth is merely recognized. This is the ordinary way of talking about legal matters.

The basic objection to this way of talking is that it fails to describe the way in which the agent confronts the rules in the process of deciding his action under them; that is, it obscures the decision the agent must make in his actual situation. And at the same time, for that reason, it obscures the fact of what we may call nonsytematic change in accommodating conflict. To be sure, legal change occurs to the ordinary way of thinking, but always systematically, within established ehannels through the exercise of delegated authority. The system expands; the system contracts; but expansion or contraction occurs through means, like the introduction or repeal of statutes, that are, so to speak, part of the manifest content of the system.

Now our point, as the jury acquittal illustrated, is that systems change also when lines of development in a complex institution, each of which represents different values, come into conflict under the stress of particular circumstances. If systems are not complete historically it is not only because the dialectic of conflict propels incessant changes. More important here, systems may be incomplete because, in consequence of the development of different lines of interest and value within the same institution, determination of which line of development and in-

77. See generally Cappelletti, Judicial Review in Comparative Perspective, 58 Calif. L. Rev. 1017 (1970). 
terest shall be honored in particular cases inust be thrown back upon individuals who necessarily receive only incomplete systernatic guidance for their decisions. So we speak of nonsystematic change through rule departures. Legitimated interposition, then, constitutes a partial explanation of how, short of revolution, the legal system accommodates change.

There is another, related way of speaking that would seein to deny us rule departures and hence cloud the accommodation to conflict and incompleteness which characterize legal systems. One might say: "You think you have found the legal system legitimating departures from its own rules when in fact you have found the legal system not legitimating rule departures but authorizing the deployment of different principles and policies to which different weights may be assigned."78 The actual process of confronting conflicted demands is absorbed into entities called principles or policies, with the consequence of enhancing the authority of the legal system.

Our response is that there are no principles or policies in themselves, but that directives of the legal system become rules, policies, or principles through the manner of their use. Their use does not follow from their nature, but their nature from their use. Generality, vagueness, and precision do not determine whether directives function as principles, policies, or rules. The critical determinant, we propose, would be the way such directives functioned in a context of directives; and we would say that when they work in such a way in that context that departures from them may be legitimated, then those directives tend to be adjudged principles and policies and not merely rules. Whether a "Keep off the grass" sign states a policy or a rule will depend on whether that directive exists in a complex of directives such that sometimes the obligation to keep off the lawn cannot be maintained simultaneously in the instant case with other legally recognized obligations. Then, the fact accepted, it becoines a policy or principle to which we ascribe a certain weight. Similarly the status of stare decisis depends on whether other legal obligations (assuming stare decisis represents an obligation) stand against it or not. If they do not, it functions as a rule; if they never did, we would without inuch hesitation call it, precisely, a rule. But if they do, we speak of the principle or pohicy of stare decisis.

78. Compare Dworkin's distinctions among rules, principles, and policies that might make sucl an objection possible. Dworkin, Judicial Discretion, 60 J. PrII. 624 (1963); Dworkin, The Model of Rules, 35 U. ChI. L. REv. 14 (1967), in LAW, ReAson, AND JUSTICe 3 (G. Hughes ed. 1969). Discussion of the implications of Professor Dworkin's analysis for the positions we lrave adopted on rule departures lies-outside the scope of this Article. See Shuman, Justification of Judicial Decisions, 59 CALIF. L. Rev. XXXX (1971). 


\section{IV}

\section{OTHER INSTANCES OF LEGITIMATED INTERPOSITION}

Our purpose is not to present a systematic canvas of our legal system with respect to the occurrence of legitimated interposition. However, to stop with the criminal jury would leave unanswered the possible objection that we are making a theoretical mountain out of a singular and anomalous legal molehill. It will be helpful, therefore, to show that legitimated rule departures by officials are a familiar feature of our legal terrain.

\section{A. The Police}

American statutes and municipal ordinances do not explicitly confer discretion upon the police as to the laws they slould enforce, the circumstances in which they sliould enforce them, or the persons they should enforce the laws against. ${ }^{79}$ The criminal laws of a state represent the legislature's determination of that conduct that is forbidden on pain of punishment, subject only to those exceptions and qualifications that the legislature itself provides. Those laws delegate to the police no dispensing or remitting power or the general power to make further exceptions. The duty of the police as reflected in these laws is to enforce the criminal law enacted by the law-making authority-not when they think it just, or where it is not inconvenient, or where they think it not unduly costly. State laws and local ordmances sometimes make this obligation explicit. ${ }^{80}$ But even in the absence of an explicit statute these obligations follow from the traditional connotations of the policing function. ${ }^{81}$

It is well known, lowever, that despite this formal rule of competence the police in fact exercise a wide range of cloice in deciding whether to arrest even in cases where probable cause is manifest. ${ }^{82}$ Sometimes the basis for not arresting arises from the police perception that the legislative purpose in making conduct criminal would not be served by arresting all persons who engage in the prolibited conduct. Instances include deliberate nonenforcement of the gambling laws against

79. Goldstein, Police Discretion Not to Invoke the Criminal Process, 69 YALE L.J. 543, 557 (1960). An exception is N.M. STaT. ANN. § 39-1-1 (1954), making it the duty of peace officers to file complaints "if the circumstances are such as to indicate to a reasonably prudent person that such action should be taken."

80. See W. LAFAVE, ARREST 76 (1965); Goldstein, supra note 79, at 557; K.C. Davis, supra note 6, at 84-88.

81. See Goldstein, supra note 75 , at 547; cf., e.g., People v. Woodward, 220 Mich. 511, 515, 190 N.W. 721,723 (1922).

82. The examples which follow are chosen from the data collected in W. LAFAve, supra note 80, at 83-143. 
social gamblers, even though the laws make so such exception, on the ground that the inclusiveness of the statutes is designed only to prevent commercial gamblers from escaping; of legislation prohibiting extramarital or deviant sexual behavior between adults, on the ground that the laws don't really reflect a community judgment that this conduct should be criminally punished; of laws thought to be obsolete. Other times the basis for nonenforcement is the need to conserve police resources, leading to judgments that certain violations (traffic, juvenile, drunkenness) are too trivial to warrant arrest; or that what are generally regarded as serious violations are not so regarded by the cultural subgroup in which they occur (an intrafamily knifing in a Black slum, for example, where the victim does not imsist on prosecution); or that the concern of the victim of a mimor offense is restitution, as in some cases of shoplifting or passing bad cliecks; or that the victim has brought it on himself, as the patron defrauded by a defaulting prostitute. Then there are nonenforcement situations which do not fit into any discrete category. We learn that police often respond to local community preferences, for example, by permitting gambling to continue in local taverns where local citizens want it to; that they may decline to arrest an informant (narcotics users, for exainple) because of his usefulness in apprehending more serious offenders; and that, as would be expected, they often do not arrest in a wide range of cases where they judge that the personal harm that would be done to the offender outweighs the law enforcement gams that would be achieved by arresting.

It is plain from all this that the police in their day-to-day work are in fact making their own judgments of whether or not to enforce the criminal law. Sometimes the judgments are made by the department; more often they are made by the officer himself. Yet no law purports to vest this dispensing power in the poticeman. Is lie a usurper of law when he makes these judgments? Those familiar with the criminal justice would surely not say so, for the system in a nuniber of ways shapes a role for the policeman which allows for his self-determined decision not to enforce the criminal laws.

That police engage in choices of this sort is widely understood. Professor Davis observed that "the strongest argunent for [police policymaking] rests upon legislative inaction in the face of long-continued police practices." $" 83$ To some substantial extent the exercise of such an authority is invited both by the existence of statutes that overreach their real target, thereby requiring law enforcement to make discretionary enforcement decisions, and by the retention of laws that few expect the police to enforce at all. Moreover, this police authority is re-

83. K.C. DAvis, supra note 6 , at 84 . 
garded widely by responsible sources to be both inevitable and desirable. So, for example, a Presidential commission states as the most important factor accounting for nonenforcement decisions "an entirely proper conviction by policemen that the invocation of criminal sanctions is too drastic a response to many offenses." Judge Breitel has stated, "If every policeman . . . performed his . . . responsibility in strict accordance with rules of law, precisely and narrowly laid down, the criminal law would be ordered but intolerable." ${ }^{\prime 85}$ The arguments of Professor Davis, a severe critic of uncliecked policymaking by police, are apt for our purposes. He writes:

Legislative bodies have long acquiesced in the assumption of power by the police, legislation has long been written in reliance on the expectation that law enforcement officers will correct its excesses through administration, the legislation often reflects unrealistically high aspirations of the community and hence compels the law enforcers to temper the ideals with realism, and the system we have is the product of natural evolution through responses to the multiplicity of community needs. ${ }^{86}$

In addition to the evidence of public and legislative acceptance of and reliance upon interpositional decisions by the police, the absence of any substantial legal sanctions against sucli decisions serves, as in the case of the jury, to reinforce a right of the police to make them. To be sure, the individual policeman is subject to administrative sanction if he contravenes departmental policy (and if he is discovercd). But the police agency as a whole is substantially immune to legal recourse.

Equally significant is the power of the police, again like the jury, to determine final legal consequences beyond its authority as expressed in the rules of its competence. Although not on a par witl a jury's acquittal, which is always final and absolute, a police decision not to arrest a violator generally ends the matter. Of course, a police decision does not affect the legal status of the violator, who may subsequently be arrested for the saine offense-perliaps by another officer, by a citizen, or pursuant to the complaint of an aggrieved party: there is no guarantee against double jeopardy liere. Nevertheless, in the overwhelming majority of cases a police decision not to invoke the criminal process is, as a practical matter, dispositive.

84. U.S. PRESTENT'S COMM'N ON LAW ENFORCEMENT AND THE ADMINISTRATION of Justice, The Challenge of Crime in a Free Society 106 (1967). (1960).

85. Breitel, Controls in Criminal Law Enforcement, 27 U. CH. L. Rev, 427

86. K.C. DAvis, supra note 6 , at 87 . 
A police department decision not to invoke the criminal process at all against certain defendants in certain kinds of circumstances is almost, although not quite, as free of judicial recourse as a jury decision to acquit. The proof of this is largely negative: the absence of legal provisions for recourse in the face of widespread and generally known practice of police nonenforcement. But one recent case from England-a rare instance of an attempt to invoke judicial review of police nonenforcement-is informative. ${ }^{87}$ A private individual sought mandamus to compel the Metropolitan Police Commissioner to abandon his policy of not enforcing the gaming laws against London casinos except on coinplaint. The court's analysis reveals the amplitude of police nonenforcement authority. It was the Police Commissioner's duty to enforce the laws, said the court, but no governmental official has the power to compel him to discharge that duty. "The responsibility for law enforcement lies on him. He is answerable to the law and to the law alone."88 In many fields, said the court, there could be no interference: in deciding in any particular case whether to make imquiries or to arrest; in deciding on the disposition of the force; indeed, even in deciding on a policy of not enforcing the law in certaim kinds of cases, such as the case of not enforcing the law against attenpted suicide. The court suggested that the police are judicially answerable only in the exceptional case, perhaps like the one before the court, where there is a deliberate policy of nullifying a law without basis in legislative intent or social policy. ${ }^{89}$ But, of course, this is plainly to say that the police are free and unanswerable to the law in invoking sucli nonenforcement policies in all other kinds of cases.

In discussing the jury we found that another condition was necessary to support a conclusion that an official's power to depart froin a rule of competence represented an instance of legitimated interposition: the system inust make available to the official some set of ends in virtue of which his departing from the rule may be justified. We argued that this condition existed to the extent that rule departures became an accepted pattern of the official's exercise of power and generally served purposes consonant with those of the legal system. The condition would appear plainly present in the case of the police official who declines to arrest. Legislative rulemaking is a coarse tool, and the collaborative alliance of the law enforcement official inakes possible a more sensitive and discriminating regime of social control. Delegated discre-

87. Regina v. Commissioner of Police, [1968] 2 W.L.R. 893 (C.A.).

88. Id. at 902 .

89. Id. at 903-04. Fortunately, the court did not have to reacl this question in the instant case because it had become moot: the Commissioner had already revoked his policy of nonenforcement with respect to the gaming laws. Id. at 904 . 
tion, of course, would achieve this alliance, and in very many respects in a far better way, principally because it makes decisionmaking more visible and more amenable to checks and controls. But an advantage of the interpositional strategy is that it allows the official rule of full enforcement to be maintained while at the same time pernnitting the exercise of individualized judgment. This is not idle ceremony. A criminal code has symbolic offices to fill. The unequivocality of the criminal prohibition and of the threat of punishment for those who transgress contribute something - how muclr is problematical-to the deterrent and moralizing force of the criminal law. Relying on police interposition avoids proclaiming on the face of the prohibition that it is not meant to be taken literally. Furthermore, it avoids affronting the rule-of-law ideology by overt recognition of the extent to which important matters, even those directly affecting the liberty of the citizen, are left to the official's discretion..$^{90}$

The point we are liere putting is not that it is better for the police to be permittcd to operate outside the rules than to recognize their discretionary authority and to seek to check, control, and structure it in order to assure rationality, uniformity, and public responsiveness. Proposals to recognize discretion are increasingly being made, and with force. The point is rather that the device of not formally delegating the discretionary authority and relying upon the police to inake-liopefully - sensible and sensitive judgments outside the stated rules of their competence is an alternative strategy that serves identifiable social purposes.

So much, then, for the general argument that the police decision not to arrest a guilty person, like the jury decision to acquit a guilty person, may be viewed as an instance of legitimated interposition. This is not to say, llowever, that the posture of a policeman with respect to rules

90. A similar point was recently made by Louis Jaffe in commenting on Kenneth Davis' argument that the grounds of police discretion should be explicit and public. Davis made his point by drafting a formal statement of policy on the use of informers embodying the actual, but covert practices of the police in order to show how explicit delegated discretiou and the requirement of open policy formulations would reveal the indefensibility of those practices. Jaffe's observation is appropriate to our argument on the social uses of interpositional rule departures:

His drafting does point up all that is questionable about these practices but it is not easy to imagine a draft which would be acceptable. What is the alternative? That depends on whether there is or is not general approval of the use of informers. I believe that there is approval in a kind of covert, perhaps shame-faced way. If there is such approval, it involves inevitably the acceptance of the arbitrary discretion embodied in Davis' regulation. Little would be gained by the regulation other than making public what the society prefers not to make public. This under-the-counter approach may offend the Puritan, it may offend the legal theorist, but I am sure that those who are offeuded are in the rather small minority, and if a society-a democracy if you will-chooses to operate that way, the appeal to general principles of equalprotection and formal legality does uot seem to ine to be sufficient.

Jaffe, Book Review, 14 VILL. L. Rev. 773, 777 (1969). 
of competence is altogether the same as that of a juror. It has already been noted that while the jury's power is de jure to render determinate and unchallengeable consequences, the policeman's power to do so is de facto. But there is another difference of greater interest which casts further light on the phenomenon of legitimated interposition.

In the case of the jury we faced the issue of whether it was indeed a rule of the system that juries were obliged to apply the court's legal instructions to the facts found and concluded, for a variety of reasons, that it was. It is not as clear, however, that there is a rule obligating a policeman to arrest all persons lie reasonably believes liave committed a crime. The conventional principle of nonselective police enforcenent has been subject to extensive public examination, particularly in the past decade. Public reports have dwelled at length and in detail on the regularity and frequency with which policeinen depart from that principle in their daily tasks and there are increasing pressures to recognize a different operating rule that would rationalize and improve the quality of arrest decisions by explicitly recognizing the discretionary authority of the policeman. ${ }^{01}$ Moreover, the policeman's decision not to arrest the guilty, unlike the jury decision not to convict the guilty, is both frequent and visible to large numbers of observers and participants. What einerges, then, is that the evidence for the legitimacy of selective nonarrest decisions has become so great that it makes problematical the status of the rule of competence that purports to deny the policeman authority to make such decisions. Once the rule may be departed from whenever the official believes it better on balance to do so, rather than - solely where he is persuaded by overwlielming justification, we may not properly speak of the rule as binding at all.

Whether, in light of all the evidence, one slould conclude that police are indeed departing from an authoritative rule of competence in declining to arrest apparently guilty persons or, on the other hand, that the rule of competence has so lost its vitality that it is improper to speak of rule departures in these cases, seems to us fruitless to pursue. What is leelpful about the police situation is the further liglit it casts on the nature of role adjustunents historically and on legitimated interposition as an argument of justification for departing from rules.

It would, after all, be surprising to find official roles as they actually exist so nicely aligned that one could clearly say about any given exercise of authority that it was either within a delegated discretion (and hence no rule departure at all) or outside that discretion and a rule departure, whether legitimated or not. Role authority is a matter of law, and there is no reason to expect the law here to be any clearer than it is

91. K.C. Davis, supra note 6 , at 87 . 
in other areas. Arguments over the existence and limits of discretion range in degrees of persuasiveness. In the police instance the argument for selective enforcement is strong. Whether the justifying argument is more persuasively cast in terms of legitimated interposition or in terms of the absence of a mandatory rule is arguable. Yet the imdeterminateness of the argument for interposition in a given case scarcely detracts from the form and identity of legitimated interposition; and that, after all, is the main burden of our argument.

The police instance reveals something else about role adjustments: not only are definitions of role authority indistinct and arguable, but they may be changing. In any dynamic system there will be constant adjustment in the total response of the legal system to official role demarcations. An assumption of authority to act at one stage of development may constitute a plain usurpation of power. In time changes may occur through which the actions become justified as an instance of legitimated interposition. Further changes may transform the context in a way that allows us to say that the actions are justified by exphcit, delegated discretion. Something of this evolution may be represented in the instance of the police, which is somewhere $m$ the transition between the second and third stage, if not already in the third. It should be noted, lowever, that there is nothing inevitable about this line of development. In the case of the jury, for example, the progression was different. In the early stages of formalization of the law, there emerged a rule requiring adherence to the judge's instructions with no interpositional privilege to depart. Then followed a variety of developments establishing a firm case for legitimated interposition. But the further movement towards an explicit, delegated discretion, though strongly argued, failed, and legitimated interposition became a more or less steady state.

\section{B. The Prosecutor}

As in the case of the police, a stated legal tradition surrounds the prosecutor's role with substantial restraining norms. Writing in the early thirties, Thurman Arnold listed among the basic assumptious of the law enforcement creed: "It is the duty of the prosecuting attorney to enforce all criminal laws regardless of his own judgment of public convenience or safety." rests on the proposition that the law forbids "the injection of the prosecutor's private notion of criminal policy into the public policy of the

92. Arnold, Law Enforcement-An Attempt at Social Dissection, 42 YALE L.J. 1, 18 (1932). See also Snyder, The District Attorney's Hardest Task, 30 J. CRIM. L.C. \& P.S. 167,168 (1939).

93. State v. Winne, 12 N.J. 152, 96 A.2d 63 (1953). 
state." The general statutes defining the prosecutor's duties speak of his duty to initiate and carry out prosecutions of the criminal laws, with no qualification that the prosecutor may do otherwise if he deems it inopportune or unjust. As Baker observed in his classic study:

The duties of the prosecutor, as set forth in the statutes, say nothing about compromise or adjustment, bargaining with defendants, mediation in quarrels, or crime prevention. On paper, the rules for the administration of the criminal law provide that all offenders should be treated equally-no defendant should receive more or less punishinent than another who cominitted a similar offense $\ldots .95$

Sometines courts flatly assert that the duty to prosecute imposed by such statutes is "mandatory and not discretionary."98 Moreover, numerous statutes expressly require the prosecutor to prosecute specified offenses - usually offenses like liquor and gambling, but also others that have given rise to particular public alarm or concern about enforcement. ${ }^{97}$

As for recourse, laws in various states do provide some remedies agamst prosecutorial nonenforcement decisions. There are provisions authorizing his removal and criminal prosecution. In addition state attorneys general often are empowered to supersede him and initiate prosecutions themselves. ${ }^{98}$ These, however, tend to be limited to cases of manifest bad faith and scarcely touch the vast majority of prosecutorial judgments. ${ }^{99}$ While other remedies against a prosecutor's inaction

94. Ferguson, Formulation of Enforcement Policy: An Anatomy of the Prosecutor's Discretion Prior to Accusation, 11 RUTGERS L. REV. 507, 515 (1957).

95. Baker, The Prosecutor-Initiation of Prosecution, 23 J. CRm. L.C. \& P.S. 770, 770 (1933). See also Baker \& DeLong, The Prosecuting Attorney-Powers and Duties in Criminal Prosecution, 24 J. CRIM. L.C. \& P.S. 1025, 1034, 1064 (1934).

96. City of Merced v. County of Merced, 240 Cal. App. 2d 763, 766, 50 Cal. Rptr. 287, 289 (5th Dist. 1966). See also In re Voss, 11 N.D. 540, 546, 90 N.W. 15, 18-19 (1902): "The duties of state's attorney are to be performed regardless of public sentiment, and le who administers that office in deference to sentiment opposed to the law is unfit to hold that office or to be an attorney at law."

97. See Baker \& DeLong, supra note 95, at 1034-45; Note, Prosecutor's Discretion, 103 U. PA. L. Rev. 1057, 1058 (1955); e.g., CaI. Penal Code $\$ 335$ (West 1971) ("Every District Attorney, Sheriff, Constable, or police officer must inform against and diligently prosecute persons whom they have reasonable cause to believe are offenders agamst the provisions of this Chapter [Gaming], and every such officer refusing so to do, is guilty of a misdemeanor."); CAL. AGRIC. CODE $\$ 8$ (West 1971) ("The district attorney of any county in which a violation of any provision of this code [Agriculture] occurs shall, upon request of any enforcing officer or other interested person, prosecute such violation."); Board of Supervisors v. Simpson, 36 Cal. 2d 671, 227 P.2d 14 (1951) (duty to prosecute action to abate nuisance is mandatory).

98. Full scale descriptions of the legal controls available may be found in $F$. Miller, Prosecution: The Decision to Charge a Suspect With a Crime 293-337 (1969); Note, supra note 97, at 1075-80.

99. See Remington \& Rosenblum, The Criminal Law and the Legislative Process, 1960 U. IrL. L.F. 481, 498; Ferguson, stupra note 94, at 523; Comment, Private Prosecution: A Remedy for District Attorneys' Unwarranted Inaction, 65 YALE L.J. 209, 209. 15 (1955); Note, supra note 97, at 1076, 1079. 
may also be occasionally available, ${ }^{100}$ it remains true that though his self-determined power not to prosecute is less than the power of the police to decline to arrest, it is nonetheless substantially uncon. trolled. ${ }^{101}$ Whether the conceptual rationalization is found in the role of the prosecutor as attorney for his client, the state, ${ }^{102}$ or in the exclusive nature of the prosecuting function, ${ }^{103}$ or in the principle of separation of powers between executive and judicial functions, ${ }^{104}$ the result that emerges is substantial nonaccountability to the judiciary for the prosecutor's noncorrupt exercise of his power not to initiate criminal prosecutions. ${ }^{105}$

Nonetheless, the argument for legitimated interposition based on the absence of effective means for enforcing the prosecutor's legal duty to prosecute provable crimes is weak. While prosecutors do in fact make judgments not to enforce on a vast scale, ${ }^{106}$ the legitimacy of their doing so is so pervasively and authoritatively recognized that full enforcement, even more than in the case of the police, cannot be regarded as a rule at all. In our terms, deviational discretion has become substantially converted into delegated discretion: "It is undoubtedly part of the prosecutor's job to individualize justice."107 So, for example, Chief Justice Burger, while a judge on the D.C. Circuit, observed: "Myriad factors can enter into the prosecutor's decision ... . [H]e is expected to exercise discretion and common sense . . . .108 Judge Burger was not making new law. An earlier court has stated: "The discretionary power of the attorney for the United States in determining whether a prosecution should be comnnenced or maintained may well depend upon matters of policy wholly apart froin any question of probable cause "109 Indeed, it is pervasively accepted that a vital part of the offi-

100. See note 98 supra.

101. See Comment, supra note 99 , at 211-15.

102. Newman v. United States, 382 F.2d 479 (D.C. Cir. 1967); United States v. Brokaw, 60 F. Supp. 100 (S.D. III. 1945); 2 OP. ATT'Y GEN. 482, 486 (1831).

103. Confiscation Cases, 74 U.S. ( 7 Wall.) 454 (1868).

104. United States v. Cox, 342 F.2d 167, 171 (5th Cir. 1965): "It follows, as an incident of the constitutional separation of powers, that the courts are not to interfere with the free exercise of the discretionary power of the attorneys for the United States in their control over criminal prosecutions."

105. See Ferguson, supra note 94, at 510.

106. Baker, supra note 95, at 770: "Actually ... the prosecutor is the father confessor' of the community, and whether or not a particular offender is prosecuted depends very largely upon the personal reactions (or judgment) of the prosecutor." Jackson, The Federal Prosecutor, 24 J. AM. Jud. Soc'y 18, 18 (1940): "The prosecntor has nore control over life, liberty and reputation than any other person in Anerica. His discretion is tremendous."

107. People v. Byrd, 12 Mich. App. 186, 197, 162 N.W.2d 777, 782 (1968) (concurring opinion).

108. Newman v. United States, 382 F.2d 479, 481 (D.C. Cir. 1967).

109. United States v. Cox, 342 F.2d 167, 171 (5th Cir. 1965). 
cial role of the prosecutor is to "determine what offenses, and whom, to prosecute," even among provably guilty offenders, and that in so doing he must "consider the public impact of criminal proceedings . . . [and] balance the admonitory value of invariable and inflexible punishment agamst the greater impulse of the quality of mercy."110 Moreover, that prosecutor discretion is an explicit part of his role is further evidenced by the fact that the overt issues for law reform today center around devising means-administrative, legislative, and judicial-to regularize, rationalize, and objectify the standards he employs in making discretionary judgments. 111

Still, to say that an official has a delegated discretionary authority to use his best judgment is not to say that there may be no boundaries generally imposed by law to give rise to legitimated interposition. ${ }^{112}$ If not all examples of prosecutorial discretion constitute interposition, it does not follow that none do. A notable and widely recognized instance of prosecutorial rule departure involves statutes that mandate severe sentences and leave no option in the sentencing judge. For example, some laws set a high mandatory punishment or deny the possibility of probation to the offenders with prior convictions and often impose a duty on the prosecutor to charge all known priors. It would be difficult to construe these legislative schemes as empowering the prosecutor to use his discretion selectively. Yet it is an elemental fact of life that prosecutors do, and often with the help of the court. As the President's Crime Comunission reported, "There is persuasive evidence of nonenforcement of these mandatory sentencing provisions by the courts and the prosecutors."113 In fact, these provisions are mvoked in only a small fraction of the cases in which they are authorized. This pattern occurs even in the majority of states where the prosecutor is statutorily obliged to charge multiple offender counts, thus producing a substantial prosecutorial nullification. ${ }^{114}$ For the same reasons we ad-

110. Howell v. Brown, 85 F. Supp. 537, 540 (D. Neb. 1949); see Pugach v. Klein, 193 F. Supp. 630, 635 (S.D.N.Y. 1961); Kaplan, The Prosecutorial Discretion, 60 NW. U.L. REV. 174 (1965); U.S. PRESDENT'S COMM'N ON LAW ENFORCEMENT AND the Administration of Justice, TASK Force Report: The Courts 5 (1967).

111. See K.C. Davis, supra note 6, at 188-214; U.S. PRESIDENT's COMM'N on LAW ENFORCEMENT AND THE ADMINISTRATION OF JUSTICE, supra note 110, at 5-9; Comment, Discriminatory Law Enforcement and Equal Protection From the Law, 59 YALE L.J. 354 (1950); Note, The Right to Nondiscriminatory Enforcement of State Penal Laws, 61 CoLUM. L. Rev. 1103 (1961).

112. See note 98 supra.

113. U.S. President's COMM'N ON LAW ENForcement AND the AdMinistration of JUSTICE, supra note 110 , at 16.

114. Tappan, Habitual Offender Laws and Sentencing Practices in Relation to Organized Crime, in Organized CrIme and Law ENForcement 123 (M. Ploscowe ed. 1952); Note, Court Treatment of General Recidivist Statutes, 48 CoLUM. L. REv. 238 (1948). See generally Symposium on the Habitual Criminal, 13 MCGILL L.J. 533 (1967). 
vanced earlier in connection with juries and police, these instances of rule departures seem to us to represent further examples of legitimated interposition-the legal system has recourse to the judgment of its officials to resolve the tension between the means delegated and the ends of their roles.

A coinparable instance of a inore general deviational discretion is the institution of prosecutorial plea bargaining. Until quite recently, the universal phenomenon of bargaining between the prosecutor and the defendant over prosecutorial concessions (such as noninclusion or dismissal of counts, reduction of charges, and sentencing recommendations) in return for a plea of guilty operated as a shadow procedure, "in the limbo of dubious legality."116 It grew up "outside of the law"116 as a device both to mitigate excessively harsh penalties and to prevent a breakdown of the system froin congestion and delay. ${ }^{117}$

The imcompatability of this process with received models of the proper exercise of discretionary authority has long been noted. The feeling is that bargain days have no place in the criminal law. Civil cases may properly be compromised, but justice and the public interest in crime prevention reflected in the criminal law may not be. ${ }^{118}$ That public interest is a function of the criminal law as it is written and of the prosecutor's conscientious exercise of discretion on the merits $\mathrm{m}$ view of the circumstances of the defendant and the crime. "However, when he goes beyond those factors and weighs the state of his or the court's backlog in the balance, he employs that discretion in a manner unrelated to the policy underlying delegation of that discretion to him." "119 Crimes and penalties may be reduced or not exacted because the defendant doesn't deserve so much, in the circuinstances, or because the social interest makes it mappropriate. But so to reduce or fail to exact the punishment in order to save the time, money, or court congestion distorts the process and works toward "de facto invalidation of extant laws." 120

Certainly there are countervailing considerations and arguments. But it is more relevant to our purposes that for generations these

115. People v. West, 3 Cal. 3d 595, 608, 477 P.2d 409, 417, 91 Cal. Rptr. 385, 393 (1970).

116. Miller, The Compromise of Criminal Cases, 1 S. CaL. L. Rev. 1, 27 (1927).

117. See McLaughlin, Selected Excerpts from the 1968 Report of New York State Joint Legislative Committee on Crime, Its Causes, Control, and Effect on Society, 5 CRIM. L. BuLL. 255, 257 (1969).

118. Miller, supra note 116; Shelton v. United States, 242 F.2d 101, 113 (5th Cir. 1957) ("Justice and liberty are not the subject of bargaining and barter.").

119. People v. Byrd, 12 Mich. App. 186, 199, 162 N.W.2d 777, 783 (1968) (concurring opinion).

120. McLaughlin, supra note 117 , at 268. 
views of the inconsistency of plea bargaining with the proper role of the prosecutor were part of the accepted jurisprudence. ${ }^{121}$ Of course bargaining nevertheless continued on a vast scale. But the courts adjusted to the situation by acting as though it did not exist, because to do otherwise would require the courts to set themselves against it (which practical considerations made unwise) or to recognize that the systein was not operating wholly lawfully. Hence the oft-noted charade in which the court asked the pleading defendant whether he received any promises or inducements in exchange for his plea and the defendant, properly coached, responded that he did not, though all present, including the judge, knew very well that the opposite was the case. ${ }^{122}$

Very recently, all this has changed. Influential commissions have publicly supported plea bargaining as productive of better results than "the straight application of the rules of law would permit."123 The United States Supreme Court recently recognized the lawful place of plea bargaining, substantially on the ground that considerations of expediency, expense, and the threat of overtaxing the system with trials are entitled to weight. ${ }^{124}$ The California supreme court followed suit, concluding, "Plea bargaining has become an accepted practice in American criminal procedure, 'an integral part of the administration of justice,' ${ }^{125}$ and requiring the terms of the agreement to becoine part of the record. In short, the institution of plea bargaining has been formally adopted and the prosecutor's role expressly redefined to embrace participation in it. But this development only serves to dramatize the antecedent status of plea bargaining as a widespread departure froin prevailing rules of competence, though legitimated by the functioning and context of the whole legal system.

\section{The Judge}

In determining whether the role of the courts provides for legitimated interposition it is necessary first to distinguish situations in which the courts act in essentially administrative ways from those in which they act in essentially judicial ways.

In many instances a judge is called upon to perforn functions that

121. See Alschuler, The Prosecutor's Role in Plea Bargaining, 36 U. CHI. L. REv. 50,51 (1968).

122. E.g., United States v. Williams, 407 F.2d 940, 947 0.11 (4th Cir. 1969); United States v. Jackson, 390 F.2d 130, 138 (7th Cir. 1968).

123. aba Project on Minimum Standards for Crimmal Justice, Standards Relating to Pleas of Guilty 45 (1967).

124. North Carolina v. Alford, 400 U.S. 25 (1971); Brady v. United States, 397 U.S. 742 (1970).

125. People v. West, 3 Cal. 3d 595, 604, 477 P.2d 409, 413, 91 Cal. Rptr. 385, 389 (1970), quoting Barber v. Gladden, 220 F. Supp. 308, 314 (D. Ore. 1963). 
are administrative in character. In these matters the fact that he is a judge in contradistinction to a jury, a policeman, or a prosecutor is plainly irrelevant. Rules are laid down to control the exercise of his delegated authority-rules of the same kind that bind these other officials. To illustrate, the judge is typically vested with the responsibility for sentencing convicted offenders. However, his discretion in sentencing is often subject to defined constraints-for example, that he may not grant probation to prior offenders. If the judge departs from this rule because he thinks it unjust, and if the context in which such judgments are exercised suggests that he does not violate his role obligation by doing so in certaim cases, we may properly speak of legitimated interposition by the judge. For example, in the illustration we just gave of statutory denials of the power of probation, it would soon be discovered that there is no appeal or other recourse by the prosecutor; that no subsequent challenge is possible; that disregard of the rule in particular cases where the judge deems it improper is widespread; that the other participants in the process calculate on the judge doing so in certaim cases; even that anticipation that the judge will be sensible enough to depart from the rule enters into the legislative strategy to adopt such a rule. Therefore, consistent with our previous analysis we may say that the legal system gives the judge a license to interpose his own judgment in place of that expressed in the rule. The following observation by a judge concerning a severe mandatory sentencing provision is not at all untypical of what is done:

This is ridiculous law, passed in the heat of passion without any thought of its real consequences. I absolutely refuse to send to prison for twenty years a young boy who has done nothing more than sell a single marijuana cigarette to a buddy. The law was not intended for such cases. I have been accused of usurping commutation and pardon powers. This is not true. I simply will not give excessive sentences and where the legislature leaves me no alternative, I will lower the charge or dismiss altogether. ${ }^{126}$

In analyzing the more difficult situations in which the court acts adjudicatively, rather than administratively, and applies the methodology and precepts of common law reasoning to the cases brought before it for decision, ${ }^{127}$ it is helpful to consider first the factors of finality and absence of recourse as they pertain to the judicial process. We argued earlier that a legal power to effect determinative legal consequences combined with the absence of any legal recourse for testing the exercise of that power against rules of competence constitutes

126. D. Newman, Conviction: The Determination of Gutti or InNocence Without Trial 178 (1966).

127. Here, of course, we are thinking particularly of appellate courts. 
evidence of a license to interpose. A similar plrenoinenon occurs also in the exercise of the judicial function by courts of last resort. Are we required to say that courts of last resort inust therefore liave license to depart froin the rules that constrain them precisely because they are courts of last resort?

Not only is this conclusion implausible as a description of the role and functions of supreme courts in our legal system, but as Professor Hart has shown, so much cannot be drawn from finality. Hart uses the instance of an umpire in a game who lias final authority to interpret and apply the rules during the course of play. Even though there is no appeal from his rulings we would never say that the umpire is free to vary the rules when he thinks it right to do so. If he did it would be a very different game. We could quite properly insist, first, that finality does not import infallibility - we can and do say he flouted the rules and criticize him for it; second, that he has an obligation, not diminished by the finality of his decisions, to call the plays in accordance with the rules-an obligation imposed by the very nature of the game and the understandings of all the participants as to what playing the game means. ${ }^{128}$

In the case of umpires in games and courts of last appeal in legal systems, therefore, finality and the absence of recourse do not themselves import a qualification of the role obligation to decide in accordance with the rules. How is it, then, that these factors have this import in the case of such bodies as the jury? Because, we suggest, in the case of umpires and courts of last resort the legal role of these bodies is precisely to interpret and apply the rules. They are the ultimate custodians of the rules, as it were, as some body has to be in any rule-governed system. What opens up the reposing of final and unchallengeable authority in official bodies to the inference that the obligation to the rules has been qualified is precisely that their actions have been insulated from the normal check and control by those custodians of the law. Therefore, in the case of courts of last resort we may not draw the inference of a license to interpose from the fact that those bodies are courts of last resort. As Justice Cardozo observed, "Judges have, of course, the power, though not the right, to ignore the mandate of a statute, and render judgment in despite [sic] of it. They lave the power, though not the right, to travel beyond the walls of the interstices, the bounds set to judicial innovation by precedent and custom. None the less, by that abuse of power, they violate the law." 129

Putting aside the circumstance of finality and absence of recourse

128. H.L.A. Hart, The CoNCEPT OF LAW 138-44 (1961).

129. B. Cardozo, The Nature of the Judicial Process 129 (1921). 
in assessing the possibilities of interposition in the judicial process, we confront the central difficulty (not present in cases in which the judge is acting administratively) of determining what are the rules of competence for judges in the judicial process. After all, when what judges are supposed to be doing and how they are supposed to be doing it are obscure, it must be equally so whether and when they are not doing so, and doubly obscure whether and when the systen makes it legitimate for them not to do so. Any full-scale treatinent of legitimation of rule departures in the judicial process, therefore, invites a full-scale treatment of the nature of judicial reasoning, a subject clearly beyond the bounds of this Article. Nonetheless, we may make some headway, at least, in examining the possibilities of judicial interposition, by using as starting points what the judicial rules of competence have been taken to be.

With the exception of extreme versions of the realist school, ${ }^{130}$ it is generally accepted that the judge does not exercise a carte blanche role. As a minimum there would be agreenent with Justice Cardozo that the "power . . . to shape the law in conformity with the customary morality is something far removed from the destruction of all rules and the substitution in every instance of the individual sense of justice, the arbitrium boni viri;"131 that one must distinguish "between the command embodied in a judgment and the jural principle to which the obedience of the judge is due."132 The content of that "jural principle" (the "rule of competence" in our terminology) is subject to widely differing interpretations. But what is striking is the extent to which courts in their judicial opinions proclaim their obedience to a principle formulated far more restrictively than that which they employ in practice.

This was one of the central observations of the realists. Much opinion writing proceeded on the principle that the judge was simply finding the law and that the conclusions reached were its ineluctable products. And yet, at least in the hard cases, it was demonstrable that the governing considerations were not the logical imevitabilities of preexisting legal principles, but assessinents of social policy, expediency, national priorities, and a vast array of other imponderables quite outside the formal law, if not wholly inside the judge. The thrust of realist criticism was that much opimion writing should be recognized for what it washypocrisy and self-deception; that the judges and the public should face squarely that the judicial process inevitably entails a far-ranging discretion to import values and policies outside the law; that certainty and mevitability be discarded. As Jerome Frank observed:

130. E.g., Hutcheson, The Judgment Intuitive: The Function of the Hunch in Judicial Decision, 14 CORNELL L.Q. 274 (1929).

131. B. CARDozo, supra note 129 , at 136.

132. Id. at 129 . 
[T]he task of judging calls for a clear head. But our judges, so far as they heed the basic myth, can exercise their power with only a fuzzy comprehension of what they are doing. When they make "new rules," they often sneak them into the corpus juris; when they individualize their treatment of a controversy, they must act as if engaged in something disreputable and of which they themselves can not afford to be aware. But the power to individualize and to legislate judicially is of the very essence of their function. To treat judicial free adaptation and law-making as if they were bootlegging operations, renders the product unnecessarily impure and harmful. ${ }^{133}$

Insofar as the realists were right in the observed conflict between judicial word and deed, what might one make of it all? One possibility is to conclude that the rules of the law count for nothing in binding the judge, and in reality adjudication consists of "judicial free adaptation and law-making." Sometimes some of the realists seenn to take this view. ${ }^{134}$ At the other end, one may conclude that the rules of the law count for everything, and the courts are simply taking advantage of their power to arrogate an authority not theirs. Still a third possibility would simply include as law, in addition to what might normally be recognized as legal materials, any conceptions of justice or social policy the judge may introduce in the course of bending the statute or precedents to his considered judgment on the merits of the case.

Now these three alternatives all rest on a common assumption already encountered: that for any legal decision there will exist a single, consistent directive from which the decision follows and that there is never a need for officials to take a decision upon themselves since all that needs to be delegated has been delegated. The same common assumption underlies the alternative interpretations, discussed earlier, of the clasl between the jury's obligation to defer to the instructions of the court and the prerogative not to do so. ${ }^{135}$ On that assumption, one simply denies, for judges as for jury, either the existence of an incurred obligation or the reality in the fabric of the law of a prerogative, or else one reformulates both obligation and the prerogative in a single, conditional directive and pretends that no conflict exists. Yet the reasons developed in the discussion of the jury make it equally mistaken to seek to account for the judicial process by any one of these three tactics. So we propose instead that the judicial role is conflicted, like the jury's, and that that conflicted role entails first, a tension between the judge's obligations to the jural principles that define his role and the ultimate ends of that role which those jural principles are designed to further, and second, a "sovereign prerogative" to depart

133. J. Frank, LAW AND THE MOdERN MIND 121 (1930).

134. E.g., id.; Hutcheson, supra note 130.

135. See part II, B supra. 
from those principles or rules when that seems the only way to secure those ends-legitimated interposition.

Though a remotely complete case for the claim that the judicial role is conflicted exceeds the possibilities of this Article, we may nevertheless seek to make one confirming point that has some weight: the widespread use of legal fictions to support conclusions not warranted by or in contravention of existing law, ${ }^{136}$ far from being evidence of simple dishonesty, constitutes the homage that judges, like other mortals, pay to imternal conflicts, and also the acknowledgement by the legal system of a judge's right to overcome those conflicts through a power of deviational discretion.

Prima facie, fictions are avoidance devices intended to circumvent responsibilities, and the fundamental question has been taken to be whether one or the other of the pulls that generate the conflict-the pull of law or the pull of the conclusion the judge feels he ought to reachis to be quashed. So Bentham was particularly hard on fictions as transparent covers for shameless usurpation. He saw the fiction as "a wilful falsehood, having for its object the stealing of legislative power, by and for hands which could not, or durst not, openly claim it, and but for the delusion thus produced could not exercise it."137 He would have them extirpated from the law, partly because they represented hypocrisy and partly because he preferred to confine the judges as far as possible. A different prescription for reforn, responsive to the first but not the second motivation, has been recently articulated by Professor Honore:

Indeed the defenders of fiction are . . . in something of a dilemma. If a judge has a limited, interstitial legislative power, then recourse to fiction is unnecessary. If, on the other hand, he has not, the recourse to fiction is unjustifiable. Benthan's criticism that judges who assume legislative power and conceal their assumption by a fiction are lacking in candor seems no less justified now than when it was first

136. L. Fuller, Legal Fictions 53 (1967):

Generally a fiction is intended to escape the consequences of an existing, specific rule of law. Thus the fiction of 'inviting' in the 'attractive nuisance' cases is intended to escape the rule that there is no duty of carc toward trespassers. But occasionally the matter is more obscure. In some cases a fiction seems to be intended to avoid the implications, not of any specific and recognized rule of law, but of some unexpressed and rather general and vague principle of jurisprudence or morals. Thus, the conclusive presumption that the donee of a gift accepts the gift, although it may lave been delivered out of his presence and without his knowledge, assumes a general principle that title cannot pass to a man without his assent. The conclusive presumption that everyone knows the law is, apparently, intended to escape an assumed moral principle that it is unjust to visit the legal consequences of an act upon a person who does not know the law. 1843).

137. Id. at 57, quoting 1 THE Works OF JeREMY BeNTHAM 243 (J. Bowring ed. 
made. All that is necessary, in order to meet it, is that judges should openly assume a limited power to apply both statutes and common law principles by analogy. ${ }^{138}$

The thrust of Honoré's criticism is that the courts are engaged in a kind of illicit dissimulation, saying one thing but domg another; since the courts recognize the inadequacy of doing what they say, the only acceptable option is for them to say candidly what they do. The trouble with this argument is that focusing upon the hypocrisy of fictions and arguing that the elimination of the hypocrisy cures the difficulty misses the essential tension in the judicial role that the fiction only serves to express. Lack of candor does not as such cause the legal fiction so that all that is needed to handle the case of the judge who feels the pull of the law and also of what he considers justice, is that the judge admit what he is doing when he decides in favor of justice-employing, in Honorés words, "a limited, interstitial legislative power." To make the justification of fictions the justification of hypocrisy is to dodge the terms of the problem which fictions, however well or poorly, manage: that, indeed, the judge is expected both to do justice and to follow the law and that he is supposed to do justice through the law-except he cannot. The fiction, therefore, is not gratuitous. The judge faces the problem not only of making the law through a "limited, interstitial legislative power." $\mathrm{He}$ faces the problem that that limited power cannot be meaningfully defimed in advance, and hence expressly delegated. The achievement of candor is not his problem, whatever the virtues of candor, any more, or less, than it was the jury's in rendering a verdict of acquittal that demanded departing from the court's imstructions.

We are led to propose, therefore, that fictions point to a power of deviational discretion implanted in the fabric of the legal system. Fictions testify to the gap between the ends of the law and its imstruments; and their continuous employment in the process of legal decision over a protracted period of time constitutes evidence that the socially organized role of judge is no hung-up role, deprived of power to escape the inevitable difficulties the cunning of events will subject it to, but rather a conflicted role, with a possibility of legitimated interpositions that in fact depends upon the obhigatory force of the inandatory rule of competence. Judicial departures from role requirements, through legal fictions and otherwise, have become a deeply ingrained and characteristic feature of the judicial process, a feature sustained by the milieu in which judges operate. So governmental agencies take judicial lawmaking into account when acting in their own roles; legal analysis and argumentation rest upon it; initiates into the legal system encounter the tension between analytical and result-oriented thinking as one of the central

138. Honoré, Book Review, 13 Naturad L.F. 170, 173 (1968). 
features of a process they are expected to master. Plainly, judicial lawmaking is no alien usurpation, but a functioning part of the legal process.

It remains now to imdicate some of the reasons why the conflicted judicial role, to which we think the place of fictions in the legal system points, may not simply be replaced, and without loss of content, by a judicial role in which the rules of competence were recast to delegate the authority to make legislative innovations in hard cases (as Honore in effect suggests those rules ought to be). First, recourse to the judge's own social and value judgments would, as a practical matter, very likely be far more narrowly confined to the extent that the rule of competence that the judge has no authority to legislate continued to be acceptcd, than were it formally recognized that the judge possessed a delegated legislative power. The effect here is comparable to the effect of officially denying the jury the authority to depart from the legal instructions of the judge. Conservatism and stability secure a heavier weight under these arrangements than they do where the grant of discretion is exphicit, and these two values are important in allowing courts to remain effective imstitutions for resolving disputes. A second practical consideration is this: for a judicial system to work, it must be accepted by the parties who submit their cases to it for adjudication. What helps to foster acceptance of judicial resolutions is the view that they are dispensing outcomes determined by law rather than by what the judge deems desirable. ${ }^{139}$

Second, the development of legal systems does not necessarily bring us to a point where there is a free choice between deciding hard cases

139. Wurzel, Methods of Juridical Thinking, in SCIENCE OF LegAL METHOD 286, 417 (Modern Legal Philosophy Series vol. 9, 1917):

A European judge is no Oriental sage who is to point out the right course to the parties by virtue of his own higher wisdom. The only authority on which everybody relies, when they assemble together, the injured party and the wrongdoer, as well as the judge, is exclusively and solely the will of the State, embodied in the laws that have been broken. This being so, the judge would hardly supply the wants of the parties if he allowed auy doubt to arise but what these commands of the State are really sufficient to settle every contention. Suppose that a decision were to read something like this: Wc cannot be quite sure what the legislator had in mind regarding the solution of this particular conflict, or whether he ever imagined that one would arise in this particlar form; but making use of the provisions of the law on the one hand, and relying on the other hand upon traditions, economic needs of the community, ethical sentiments, popular customs, and so forth, we hold that the proper way for you to act is so and so. A decision of that sort would not be a legal decision at all. The parties would simply reply, that is not what we have asked you to tell us.

Jerome Frank attacked Wurzel for the apparently patronizing and dishonest view that it helped the administration of justice for the laity to be duped. J. FrANK, supra note 133, at 234-35. But Wurzel was not prescribing; he was analyzing a social reality. As he said, the judicial process "must from the point of view of the positivistic principle 
through delegated discretion or deciding them through deviational discretion. In effect, if we are correct, delegated and deviational discretion constitute answers to different legal predicaments rather than the different answers to the same predicament. Depending upon what materials the system has absorbed and made available for the jurist's use and depending also on the movement of extralegal events, those predicaments change; and, changing, so does the prescription. The evolution of the jury role in acquittals has illustrated how historical movements generate divergent interests and tensions to which that role constitutes both consequence and response. Similarly, we would claim, for the development of legitimated imterpositions in the judicial process as partly evidenced by the employment of legal fictions: fictions have had, and perhaps they still have, although they need not have, a serious function (other than to give away our hypocrisy) given the condition of the legal systein. Therefore, the choice between deviational and delegated discretion is something more than a choice of two ways of doing the same thing, the one honest, the other hypocritical.

Third, deviational discretion performs a special function in a legal system even if, and when, deviational discretion leads to the same solutions of the class of present cases as the grant of a "limited, interstitial legislative power" (that is, delegated discretion). For suppose one does make a grant of such a limited power. Suppose that it is possible to state the limits of that authority with not much more than the normal and legitimate vagueness that characterizes most delegations of authority. Is it not still a rule of competence that has been introduced, and as a rule of competence, subject to being set aside or broken? If so, the same possibility of legitimated interposition might arise for that rule itself, as we saw in the case of the prosecutor. On the other hand, the possibility of legitimated interposition granted, there is no need to supersede rules of competence; and this special function of reducing, if not dispensing with, the need for periodically restating rules of competence is, we submit, far from trivial. For on the one hand, it enables adjustments and modifications to be made prior to the point at which the dam breaks. The judge has the option of playing the rules by ear before too much damage is done. On the other hand, we are spared what surely must be the monumental effort of reformulating in a significant way the grant of "limited, interstitial legislative power;" for it pays to remember that to secure agreements on changes im basic rules of competence for any role inevitably involves facing divergent interests and divergent senses of ap-

of research be considered itself a social and historical fact standing in need of explanation and reduction to its cause, rather than criticism or propositions of reform." Wurzel, supra, at 415. Of course it does stand in need of criticism and reform; but these must take into consideration the social and historical facts. 
propriate behavior, a rat's nest that legislators may prefer to let rest until they have no alternative but to clean it up.

Of course, judges themselves might simply declare: "We hereby agree that we have a limited, interstitial legislative authority." But put so generally, if the rule ineans something inore constraining, as presumably it does, than that each judge is free to legislate as he chooses, the declaration amounts to no more than this: The judicial role indeed legitimates interposition and does so when the merits mount so high that even an obligation to obey a rule of competence may be put aside. The power of deviational discretion is no less what it is because it is acknowledged, whatever the wisdom or unwisdom of a public acknowledgeinent. For what that power involves finally is a prerogative to take care of cases of a sort that, for one reason or another, it has been found impracticable or impossible to provide for in advance in the organization of an office.

$\mathrm{V}$

\section{The Significance of Legitimated InTERPosition}

Assuming that this study of rule departures is correct and that some legal systems sometimes inake interposition legitimate, why make the point? Surely, we do not inean to argue that the more legitimated interpositions in a legal systein the better or that whenever they occur in our own legal system it is necessarily for the best. That a legal system may itself provide justification for the departures of officials from the system's own rules seems to us, however, of fundamental importance both for the interpretation and criticism of legal institutions and for the armory of concepts necessary to grasp what sort of thing the law or a legal system might be. In order to suggest the significance of legitimated interposition and its study we shall cominent on both these points; and if it turns out, as it will, that that comment involves some restatement and reformulation of points already made, that is an advantage for concluding remarks.

Legal systems have customarily been interpreted and criticized as examples par excellence of what Max Weber characterized as a "rational bureaucratic" order. ${ }^{140}$ The rule of law then becomes the necessary condition for the maintenance of that order; sucli odd behavior of a legal system in providing justification for officials deviating from the systein's own rules becomes, if acknowledged, a defect or failure in the legal systein rather than a possible tactic to be undertaken by the system, with due regard to the merits, under certain conditions.

According to Weber, "rational bureaucratic" orders have, among others, the following characteristics: The validity of a claim to obedience

140. M. Weber, The Theory of Social and Economic Organization (1947). 
to some rule or command rests on "a belief in the 'legality' of patterns of normative rules and the right of those elevated to authority under such rules to issue commands." 141 Also,

every body of law consists essentially in a consistent system of abstract rules. . . . Furthermore, administration of law is held to consist in the application of these rules to particular cases; the administrative process is the rational pursuit of the interests which are specified in the order governing the corporate group within the limits laid down by legal precepts and following principles which are capable of generalized formulation and are approved in the order governing the group, or at least not disapproved of it. ${ }^{142}$

Now the significance of the study of legitimated interposition is, of course, not merely that it denies the interpretation of the law as a "rational bureaucratic" order. Traditionally, legal realism has insisted that the law really does not work that way; administration of the law as the application of rules to particular cases is perceived as mechanical jurisprudence; legal precepts and principles are seen not merely as unclearly given but as dubious constraints, even so far as they are given, upon the actions of officials. What is, however, moderately particular about the interpretation and criticisn of the law from the vantage point of legitimated interposition, and in some measure serves to differentiate it froin legal realism, is first, that it grants those who propose the rational-bureaucratic concept of the legal system the logical possibility of such an order; second, that it demes that that concept adequately describes all legal systems (since it does not even describe our own); and third, that it then proposes that such deviations from the rational-bureaucratic order as legitimated interpositions are not necessarily defects in the legal system. The result is a kind of legal realism without rule skepticism.

The study of legitimation grants the rational-bureaucratic version of the legal systen its logical possibility (which criticism of "mechanical jurisprudence" and legal "formalism" would seem sonetimes to dispute) at least to the extent that, in order to nuake sense of legitimated interposition, precepts and principles must exist that make a logical difference in decision and are obligatory for the official. All roles might be of the type demanded by the rational-bureaucratic ideal, if some offices are of that type, weak or strong as the resulting systenı might be. And, clearly, some offices are: some in no way grant their agents the power of what we liave called deviational discretion (for exaniple, that of a clerk).

But the rational bureaucratic system does not give an adequate description of the legal system because it is false, if legitimated interposi-

141. Id. at 328 .

142. Id. at 330 . 
tion sometimes happens, that "every body of law consists essentially in a consistent system of abstract rules." If those "abstract rules" are read broadly to include the imterests specified in the legal order as well as legal precepts and principles through which those interests are secured, and if consistency is given the strong sense necessary to make the rational bureaucratic order work--that in achieving an end or in satisfying a prescribed rule one will not thereby fail to achieve another end or fail to satisfy another requisite-there will always be possible occasions for which any body of law is, indeed, imconsistent. There will also be occasions on which any body of law capable of guiding behavior, rather than simply approving of that behavior after the act, will be incomplete.

In effect, the consistency of the system of abstract rules is the mevitable hostage of circumstance. Therefore, sometimes, consistency and the rational bureaucratic model may constitute a rational ideal and perhaps describe real situations, but such an ideal ought not be expected to work for all time and places. Of course, one always has the option of saying that for those times and places where the ideal does not work no true legal system exists; only it is hard to see what that defense gains if it turns out that the present legal system is not a true legal system.

In defense of the rational bureaucratic description, it will be claimed that phenomena such as legitimated interposition constitute defects in the legal system. Nothing on this earth is perfect, not even the law. In response, we repeat two essential points about the significance of legitimated interposition: First, legitimated interposition is a response of legal systems to their own incompatible claims and privileges - to their own inconsistencies; second, along with that response's disadvantages, it has social value. So a system that allows (judiciously) legitimated interposition is not thereby a corrupted legal system and for two reasons.

First, not merely is it the case that in the particular instance a gap might appear between the instructions of the court and those ends of justice and public acceptance that the system sought to achieve through its system of criminal justice. The gap establishes only the occasion for and the possibility of legitimated interposition. By insulating the jurors against the consequences of disobeying those instructions and by giving their judgment (in acquittals) legal finality, a prerogative is established for the exercise of a legitimated departure from the rule. Legitimated interposition is one way the legal system responds to imconsistencies-by making it appropriate for an individual in an official role to depart froin the rule. To be sure, other tactics are possible. One might withdraw immunity or finality; but then the effect would be to push the 
final decision on what interest inust give place away from the agent who makes the judgment in the imstant case. Accordingly, in leaving it to the agent to make a decision in respect of the appropriateness of deferring to an obligation, a mistake might have been committed, but the system in doing so may be said to be thereby corrupted as a legal system only if one assumes the inappropriateness of such action to begin with. It seems less misleading to say that in legitimated interposition the system responds, rightly or wrongly, to a problem.

The second reason why it is wrong to regard the setting up of a legal system to provide for legitimated interposition as an inherent deficiency in a legal system is that setting it up in that way has value. Not merely does legitimated interposition constitute one way of dealing with a problem: it constitutes a possibly useful way. It may be eminently practical, from the standpoint of efficiency, to allow the decisionmaker deviational discretion-and practical values may be considered (and disputed) in all cases of legitimated interposition we examined. But more importantly, legitimated interposition has a moral value. It throws on the agent the final responsibility for his action; he is constrained, yes-but not absolutely; he need not pull the trigger, though ordered; he need not convict on a law that he thinks will produce atrocious consequences, not when the chips are down. There is a good deal to be said for a legal system that, carefully and wisely, provides for effective superiority of individual judgments to rules. - Part of what is to be said for it is precisely the other side of what is to be said against the bureaucrat who follows the rules come what may. Legitimated interposition may make the burden of rules bearable. Also, of course, and this is the main point at the inoment, it does so by giving people a final choice. with respect to the rules themselves.

That the consequences of deviational discretion with respect to rules may be disastrous is also true. But to avoid the judgment that modifications of the rational-bureaucratic way of running human affairs constitute corruptions of the nature and purposes of legal orders we need not show that for all offices and social roles legitimated interposition is desirable, for it is not. We need only show that for some offices and social roles, under some conditions, the provision of legitimated interposition is a worthwhile gamble.

In sum, then, if there is legitimated interposition it will have at least this much significance for the interpretation and criticisin of legal institutions: it becomes the legitimate subject of a practical jurisprudence to inquire where and how provision for such interposition would serve, or not serve, the ends of the law in society. There has ceased to be any need to accept the restrictions of the rational-bureaucratic ideal in the investigation, and planning, of legal phenomena. The possibility exists 
for a practical-a "realistic"-jurisprudence to make inquiry into, and evaluation of, the properties of a legal system capable of acknowledging conflicts in what it expects of some of its officials (for example, that they give justice and follow the prescribed rules), of a legal system that throws the burden of resolving those conflicts on the individual agent rather than requiring of him that he pass the buck. No doubt, legal systems that sometimes provide officials justification for departing from purpurportedly mandatory rules will seem odd, given the normal presumption of the rational-bureaucratic framework. Nevertheless, it is hard to see why such systems are inherently irrational, although easy to see why they are less bureaucratic.

Perhaps we may, before closing, point out that the concept of justified rule departures by officials bears also on how legal systems in general are comprehended, both legal systems that approximate the rational-bureaucratic ideal, and those that in some measure open themselves up to rule departures. For if, indeed, it is a conceivable question whether a particular office within a legal system extends a power of deviational discretion, then it will not do to conceive the official's obligations under the law as generated solely by either the will of an authority or some set of secondary rules or a basic norm; for if it were so there would be no possible power of deviational discretion. In a word, the analysis of the official's obligation to satisfy his rule of competence, that it is imposed and therefore leaves him no alternative, is at best a gross oversimplification. The analysis of that obligation must, it now seems, include not only mandatory rules but also rules or principles through which the official may know whether he must accept the mandatory rule or command or whether he has a limited prerogative to depart from it. If, on the other hand, one prefers to say that the authorities and authoritative rules suffice to impose obligations on officials, then primciples will still be needed to make those obligations stick. We term these "principles of acceptance."

Principles of acceptance state the conditions under which an agent may or may not undertake the risk of departing from a mandatory rule, if there is uncertainty as to what his office requires, and the conditions under which an agent may or may not undertake a departure from a mandatory rule when there is no question about the status of that rule and its relevance to him as an official. Such principles are the major premise in any argument of the appropriateness or mappropriateness of a rule departure. They are derived from the analysis of the way the legal system organizes the office and the way that office is related to other offices in the system, as has in effect been seen in the brief study conducted above of jury acquittals, police discretion, prosecutorial discretion, and judicial imterposition. 
But not only do the prerogatives discerned in the course of that specific study constitute implicit principles of acceptance: so, in effect, does the rule of law model. The rule of law as a kind of universalized principle of acceptance may be conceived to say, "Do as you are told, and if you don't know what you are told or if you cannot for some reason do as you are told, given the complexity of the command and the perversity of the situation, pass the buck!" So it is easy enough to see why the existence of principles of acceptance is not fornally noticed. There is, on the assumption of the rule of law for official obligation, no alternative but to accept commands; hence one assumes that the acceptance requires nothing more than the command. Nevertheless, that even the rule of law constitutes a principle of acceptance will be seen when the possibility of differentiated responses to authoritative rules and commands directed to officials has been perceived.

Now the point is that there is no alternative to principles of acceptance as constituent elements in legal systems. For the official in his office is compelled by his situation, not by an idle curiosity or by sheer brass, to ask what he shall do about the commands and rules addressed to him. He faces the need for a decision in the instant case. He may mdeed be uncertain of what a rule requires of him, or what a complex of authoritative deinands require of him. Moreover, he may be certain that, somewhere along the line, to make a decision will require departing froin some rule of competence. What then is he to do? What guidelines does the systein offer him? It does offer him such guidelines, we have insisted, although under the influence of the rational-bureaucratic order and its rule of law model those guidelines tend systematically to be suppressed.

Nor can principles of acceptance be reduced either to a form of what Hart calls "primary rules" or whit he calls "secondary rules." They are not primary rules; principles of acceptance say how to handle primary rules. Moreover, their job cannot be perfornned by the secondary rules of the legal system, although it may seein otherwise when we consider Hart's assertions that a rule of recoguition furnishes "the proper way of disposing of doubts as to the existence of the rule,"143 and, "Whenever such a rule of recognition is accepted, both private persons and officials are provided with authoritative criteria for identifying primary rules of obligation." 144 Yet surely there is a misconception here, if indeed the rule of recognition is intended to tell an individual-private person or official-liow to act under a condition of uncertainty with respect to his obligation. For the rule of recognition, as "the proper way of disposing of doubts as to the existence of the rule," functions to eliminate uncer-

143. H.L.A. HART, supra note 128, at 92.

144. Id. at 97. 
tainty, or "doubt," rather than to provide guidance under a condition of uncertainty or doubt: and the two things are not at all the same. Sometimes, private persons and officials must act before they can eliminate uncertainty regarding the law. How then are they to act? What may they take upon themselves, what may they not? The rule of recognition tells when one has made the right move; it gives no guidance before one knows what the right move is, a knowledge systematically screened from instant availability by a series of courts that reserve the riglt to pass on such issues. Similar considerations apply if other secondary rules are construed to determine whether a mandatory rule may properly yield place, assuming that a real problem exists whether such a rule is to yield place or not.

Generally, then, the acceptance of legitimated interposition would seein to require expanding the concept of law to include functioning principles of acceptance as well as primary and secondary rules. Those principles of acceptance seein to have at least the utility of illuminating in some sinall ineasure what it means for an official to have an obligation in the legal system. We make these observations not to finish off the issues on which they impinge, but rather to suggest the value even for theoretical purposes of exploring further the departures of officials from rules.

Beyond that we are left with a question that is the proper topic of another essay: Are there principles of acceptance, legally grounded, that work for private persons, and do these principles ever justify private persons departing from a preemptory rule? 


\section{California Law Review}

\begin{tabular}{lll}
\hline VOL. 59 & JUNE 1971 & No. 4 \\
\hline
\end{tabular}

\section{BOARD OF EDITORS}

Notes \& Comments

Kent Sinclatr, JR,

D. RebeccA SNow

Peter J. Aschengrenner

JAMER R. FARRAND

PAUL E. GiLbert

Paul W. GlenN

MIChaEL L. MEYRRS

Bruce S. Ross

KeNT A. RusserL

JaMrs Tolmdano

Executive Editor

WILLIAM BILIINGSLEA, JR.

Merruck John Bobb

Wintiam M. ChamberLatn

Diane D. EAMies

ROBERT ERICSON

GENB HARTER

DAVID M. ACHTERKIRCHEN

ROBERT C. BARRETT

STEVEN A. Brick

LAWRENCE R. BROWN

- Mary Jo Christensen

JoHN F. Davis

STEVEN M. DRUKER

HENRY C. EAMES, JR.

AUDAN ANN EISENHARDT

Crardes R. Farrar, Jr.
Editor-in-Chief

JOSEPH T. KIERER

Chief Managing Editor

ROBERT D. EVANS

\section{Articles}

WIIIIAM F. COOK

Streven FinelL

Douglas AIAN Oglesby

Maria Tankenson

\section{Managing}

DarVish M. KoRdestani Micharl GeORge KozAK JOHN E. MASON, JR.

RICHARD L. PARRISH

Associate Editors

ELLYN A. Hershman

JUDITH G. KI.EINBERG

Robin MEAdOW

LAWRENCE B. ORDOWER

Richard L. Perez

JAMES C. FowLeR

Harold FrIEDMaN

Carol G. HaMgMetT

DaVID L. HaMametr

JMMMIS HARRIS

ROBERT L. HARRIS

SPENCER R. KAITZ

DENAIS S. KARJALA

SzRIIA S. Kato

RICHARD MARCUS

Thomas M. MURRAY

Administrative Aide

Susan G. Veas
Research

G. KIP EDWARDS

David R. ANDrews

Charles h. Hurd

Douglas M. Laurice

ROBERT LEVY

Book Reviews

J. Michart BrenNAN

MARY DUNLAP

Supreme Court Editor

GREGORY J. HOBBS, JR.

Omar Petrona

Peter E. Sheghan

MARgaret SHerwood

MrChaEl B. StMON

ROBERT D. STRATMIORE

Carol Bruch Myers

ElanNB T. Nezson

LYNN H. PASAROW

ReX PERschbaceibr

Thomas B. RosenBero

ROBERT K. SCHIEBELHUT

Marx Harold SHenfield

Susan J. TaMura

SCOTT R. WILLERT

STEPHEN ZAMORA 